\title{
THE TRACE METAL CHEMISTRY OF A TROPICAL HYPERSALINE BASIN: EVIDENCE FROM FIELD AND LABORATORY EXPERIMENTS
}

\section{QUIMICA DE METALES TRAZA DE UNA LAGUNA TROPICAL HIPERSALINA: EVIDENCIAS DE EXPERIMENTOS DE LABORATORIO Y CAMPO}

\author{
Laurence D. Mee 1 \\ José I. Osuna-López ${ }^{2}$ \\ 1 Marine Environmental Studies Laboratory \\ International Atomic Energy Agency \\ International Laboratory of Marine Radioactivity \\ 19, Avenue des Castellans \\ MC-98000, Mónaco \\ 2 Estación de Investigaciones Marinas Mazatlán \\ Instituto de Ciencias del Mar y Limnología \\ Universidad Nacional Autónoma de México \\ Apartado Postal 811 \\ Mazatlán, Sinaloa \\ México
}

Ciencias Marinas (1991), Vol. 17, No. 4, pp. 19-46.

\begin{abstract}
Field observations were made of the distribution of trace metals in water and sediments along a chlorinity gradient from $20-160 \%$ oo in the seasonally hypersaline Ceuta lagoon, Sinaloa, Mexico. The observations revealed a non-consecutive behaviour of the metals (with respect to chlorinity) with a rapid loss of metals to the sediments from chlorinity $20-50 \%$ oo, a net desorption of metals from the sediments from $50-155 \%$ oo and finally, precipitation with halite or the last bitters.

Radiochemical laboratory experiments were performed to examine possible solid-solution formation of $\mathrm{Ni}, \mathrm{Co}$ and $\mathrm{Mn}$ with the calcium carbonate and gypsum phases formed during seawater evaporation and the partition of $\mathrm{Co}$ and $\mathrm{Mn}$ between suspended sediments and seawater throughout the chlorinity range of the lagoon. From the laboratory experiments and a simple descriptive model of a hypersaline basin, it was concluded that the behaviour of trace metals in the lagoon results from variations in the adsorption/desorption equilibria with the sediments rather than solid solution formation.
\end{abstract}

\section{RESUMEN}

Se realizaron observaciones sobre la distribución de metales traza en agua y sedimentos, a lo largo de un gradiente de clorinidad desde 20 a $160 \%$ oo en la laguna Ceuta, hipersalina estacionalmente, Sinaloa, México. Los resultados muestran un comportamiento no conservativo de los metales (con respecto a clorinidad) con pérdida rápida de metales hacia el sedimento entre 20-50\% $/ 00$ de clorinidad, una desorción neta de metales desde el sedimento entre 50-155\% finalmente, precipitación con los últimos constituyentes de la salmuera o con halita. 
En el laboratorio se efectuaron experimentos radioquímicos para examinar posibles formaciones de sólidos en solución de $\mathrm{Ni}$, Co y $\mathrm{Mn}$ con el carbonato de calcio y fases de gibbsita formadas durante la evaporación de agua de mar y la partición Co y $\mathrm{Mn}$ entre sedimentos suspendidos y agua de mar en el intervalo de clorinidad de la laguna. De los experimentos de laboratorio y un modelo descriptivo simple de la laguna hipersalina, se concluye que el comportamiento de metales traza en la misma resulta de variaciones en el equilibrio adsorción-desorción en los sedimentos, en lugar de la formación de sólidos en solución.

\section{INTRODUCTION}

Very little is known about the behaviour of the minor elements in seawater during its evaporation and major ion precipitation. This is surprising considering the economic importance of salt production from seawater and the widespread occurrence and geological significance of ancient evaporite deposits (Borchert, 1965). Between the early work of Usiglio (1849) and the review by Borchert (1965), little progress was made on the mechanism of salt deposition though considerable attention had been paid to the mineralogy of the cvaporites themselves (scc, for example, Holser, 1979a). Since then, studies have been conducted of natural hypersaline systems to examine the major ion composition (Herrmann et al., 1973; Fernández and Mee, 1980; Krumgaltz et al., 1980 and Fernández et al., 1982), halides, alkaline elements and stable isotopes (reviewed by Holser, 1979b), the carbonate system (Lazar et al., 1983) and their general environmental conditions (Copeland, 1967). No studies appear to have been published of the transition series trace metal composition of these systems prior to the present one.

Modern day natural salt deposition is restricted to sabkhas and small epicontinental basins (coastal lagoons) in arid regions (see Mee, 1978). Ancient evaporating basins were often much larger and the presence of vast evaporite beds below more recent sediments in the Mediterranean suggests that this entire sea was evaporated, virtually to dryness, in the past (Hsu, 1972; Hsu et al., 1977). The 125 coastal lagoons of Mexico (Lankford, 1977) present a great variety of chemical environments largely dependent on the balance between evaporation and freshwater supply to them (runoff and rainfall) and tidal flushing. Several of the lagoons are hypersaline and some are managed for commercial salt production. The present report describes the distribution of some trace metals and alkalinity in such an environment and a laboratory

\section{INTRODUCCION}

Existe poca información sobre el comportamiento de los elementos menos abundantes durante la evaporación y precipitación de los iones más abundantes del agua de mar. Esto es sorprendente considerando la importancia económica de la producción de sal a partir de agua de mar y la amplia ocurrencia y significancia geológica de los depósitos antiguos de evaporitas (Borchert, 1965). Entre los trabajos iniciales de Usiglio (1849) y la revisión de Borchert (1965), pocos avances se realizaron sobre los mecanismos de deposición de sal, aun cuando se ha puesto atención considerable a la mineralogía de evaporitas (ver, por ejemplo, Holser, 1979).

Desde entonces, los estudios han sido en sistemas hipersalinos naturales para examinar la composición de iones más abundantes (Herrmann et al., 1973; Fernández y Mee, 1980; Krumgaltz et al., 1980 y Fernández et al., 1982), haluros, elementos alcalinos e isótopos estables (revisado por Holser, 1979b), el sistema carbonatos (Lazar et al., 1983) y sus condiciones ambientales generales (Copeland, 1967). Ningún estudio previo al presente parece haber sido publicado sobre la composición de metales traza de las series de transición de estos sistemas.

Actualmente la depositación natural de sal está restringida a playas desérticas y cuencas epicontinentales (lagunas costeras) pequeñas en regiones áridas (Mee, 1978). Las cuencas antiguas de evaporación fueron, frecuentemente, mucho más grandes y la presencia de capas densas de evaporitas bajo sedimentos recientes en el Mediterráneo sugieren que este mar fue evaporado, virtualmente debido a la sequedad en el pasado (Hsu, 1972; Hsu et al., 1977). Las 125 lagunas costeras de México (Lankford, 1977) presentan una gran variedad de ambientes químicos dependientes en gran parte del balance, evaporación, suministros de agua dulce (precipitación fluvial y escurrimientos superficiales) y flujos de marea. 
study of the behaviour of trace metals in hypersaline conditions using radiochemical techniques.

\section{STUDY AREA}

The present study was conducted in the southern branch of the Ceuta lagoon in Sinaloa, Mexico (Fig. 1). The northern branch of the lagoon receives the discharge of the river San Lorenzowhich receives waste from a silver mining district and part of its waters irrigate a region of intensive agriculture. The southern branch of the lagoon receives no direct fluvial supply. During the predominantly dry season (November-July) evaporation in the region exceeds rainfall by about $0.5 \mathrm{~cm}$ per day (Moore and Slinn, 1984). Since the southern lagoon basin is long $(28 \mathrm{~km})$, narrow $(0.3-0.8 \mathrm{~km})$ and shallow $(0.2-1 \mathrm{~m})$, a longitudinal salinity gradient develops from estuarine/seawater in the north to a region of halite precipitation at the southern extreme During the rainy season, estuarine conditions predominate supported by direct rainfall and local runoff.

The dry season salinity gradient is commercially managed for relatively smallscale salt production in numerous shallow pans which cover more than $0.5 \mathrm{~km}^{2}$ of the lagoon floor.

\section{MATERIALS AND METHODS}

\section{Field studies}

The southern branch of the Ceuta lagoon was sampled on two occasions (May 19 and June 11) during the 1980 dry season. The sampling points (Fig. 1) were chosen on the basis of field refractive index measurements, using a portable refractometer (American Optical Inc.), in order to obtain a total of 10 samples at fairly regular salinity intervals over the entire salinity range. Samples were taken in 20 litre polythene tanks, previously cleaned with dilute $(0.5 \mathrm{M}) \mathrm{HNO}_{3}$ and conditioned with filtered surface Pacific Ocean water. The tanks were subsampled for chlorinity analysis, for which $50 \mathrm{ml}$ samples were filtered $(0.45 \mu \mathrm{m}$ Gelman filters) and stored in glass bottles.
Algunas de las lagunas son hipersalinas y son utilizadas para producción comercial de sal. El presente artículo describe la distribución de alcalinidad y algunos metales traza en tales ambientes y un estudio de laboratorio sobre el comportamiento de metales traza en condiciones hipersalinas utilizando técnicas radioquímicas.

\section{AREA DE ESTUDIO}

La presente investigación se realizó en la bifurcación sur de la laguna de Ceuta, en Sinaloa, México (Fig. 1). La región norte de la laguna recibe descargas del Río San Lorenzo, el cual es receptor de desechos de un distrito minero de plata y parte de sus aguas irrigan una región agrícola intensiva. La región sur de la laguna no recibe suministros fluviales directos. Durante la predominante época de secas (noviembre-julio) la evaporación en la región excede la precipitación pluvial en $0.5 \mathrm{~cm} \mathrm{~d}^{-1}$ (Moore y Slinn, 1984), desarrollándose un gradiente de salinidad desde agua estuarina-agua de mar al norte, hasta precipitación halina en el extremo sur, el cual es largo $(28 \mathrm{~km})$, estrecho $(0.3-0.8 \mathrm{~km})$ y somero $(0.2-1 \mathrm{~m})$. Durante la época de lluvias, predominan condiciones estuarinas, sostenidas por escurrimientos superficiales locales y precipitación pluvial directa. Durante la época de secas el gradiente de salinidad es manejado comercialmente para producir sal en escala relativamente pequeña en numerosos estanques someros, los cuales cubren más de $0.5 \mathrm{~km}^{2}$ del fondo lagunar.

\section{MATERIALES Y METODOS}

En la época de secas de 1980, se muestreó en dos ocasiones, mayo 19 y junio 11 , el brazo sur de la laguna de Ceuta. Los sitios de muestreo (Fig. 1), se seleccionaron con base en mediciones del índice de refracción, utilizando un refractómetro de campo (American Optical Inc.), hasta obtener un total de 10 muestras a intervalos regulares de salinidad dentro del intervalo total. Las muestras se colectaron en recipientes de polietileno de 20 litros, preyiamente lavados con $\mathrm{HNO}_{3}$ diluido $(0.5 \mathrm{~m})$ y acondicionados con agua superficial del Oceáno Pacífico, filtrada. Los frascos se submuestrearon, para análisis de clorinidad filtrando $50 \mathrm{ml}$ de muestra (filtros Gelman, $0.45 \mu \mathrm{m}$ ) y se almacenaron las mues- 
The tanks were further subsampled for alkalinity determinations for which similarity filtered $150 \mathrm{ml}$ samples were stored, together with a drop of chloroform, in polythene bottles. Field $\mathrm{pH}$ measurements were made with an Orion portable $\mathrm{pH}$ meter and combination glass electrode calibrated with NBS buffers. During the first survey, $5 \mathrm{~cm}$ long cores were taken by hand at each station using a $5 \mathrm{~cm}$ diameter PVC tube. These were immediately cut into $0.5 \mathrm{~cm}$ sections and stored at $-20 \circ \mathrm{C}$ in polythene bags.

In the laboratory, chlorinity was determined by the conventional Mohr titration (Strickland and Parsons, 1972). Alkalinity was determined by potentiometric titration with $0.1 \mathrm{M} \mathrm{HCl}$ at $25^{\circ} \mathrm{C}$ (see Edmond, 1970) and calculation by the Gran (1952) method. Trace metals $(\mathrm{Cu}, \mathrm{Fe}, \mathrm{Mn}, \mathrm{Ni}, \mathrm{Pb}$ and $\mathrm{Zn}$ ) were concentrated from 101 filtered $(0.45 \mu \mathrm{m}$ Gelman) samples using Chelex-100 resin in the ammonium form (Riley and Taylor, 1968; Abdullah et al., 1976) and determined with a Varian 200 atomic absorption spectrophotometer. All reagents were prepared with dionized distilled water from which trace metals were stripped with a $10 \times 1 \mathrm{~cm}$ column of Chelex-100. Acids were quartz redistilled and the ammonia was prepared by isothermal distillation in teflon. For concentrating trace metals, columns of $5 \mathrm{~cm}$ length $\times 1 \mathrm{~cm}$ diameter were employed. In order to examine the effect of high ionic strength on apparent column efficiency, the effluent from each column was led into the second column which was also subsequently eluted for trace metal determination. In most cases over $80 \%$ of the total was retained in the first column but results were rejected when this figure dropped to below $60 \%$ as was the case above chlorinity $140 \% / 00$ (where the lagoon $\mathrm{pH}$ was also often very low). Blanks for the pre-washed Gelman filters were estimated by slowly filtering two 101 aliquots of an ocean water sample through five and fifteen filters respectively and then determining trace metals as above. Filter blanks were quite low (generally requiring a correction of less than $10 \%$ in the final trace metal concentrations) as has recently been noted by Bewers et al. (1985).

Sediment samples were oven-dried at $80^{\circ} \mathrm{C}$ and then leached with $2 \mathrm{M}$ nitric acid for 12 hours in teflon beakers prior to AAS determination of trace metals. This fraction tras en botellas de vidrio. Asimismo, se filtraron $150 \mathrm{ml}$ de muestra para el análisis de alcalinidad, se agregó una gota de cloroformo a cada muestra, almacenándose en frascos de polietileno. Se realizaron determinaciones de pH en el campo, con un potenciómetro de campo Orión provisto de un electrodo combinado y calibrado con buffers NBS. Durante el primer muestreo, se colectaron manualmente núcleos de $5 \mathrm{~cm}$ de largo en cada estación con un tubo de PVC, de diámetro de $5 \mathrm{~cm}$. Estos fueron inmediatamente cortados en secciones transversales de $0.5 \mathrm{~cm}$ y almacenados a $-20^{\circ} \mathrm{C}$ en bolsas de polietileno. En el laboratorio, la clorinidad fue determinada por la titulación convencional de Mohr (Strickland y Parsons, 1972). La alcalinidad fue cuantificada mediante titulación potenciométrica con $\mathrm{HCl} 0.1 \mathrm{M}$ a $25^{\circ} \mathrm{C}$ (Edmond, 1970 ) y calculada por el método de Gran (1952). Los metales traza, $\mathrm{Cu}, \mathrm{Fe}, \mathrm{Mn}, \mathrm{Ni}, \mathrm{Pb}$ y $\mathrm{Zn}$ fueron concentrados desde 101 de muestra filtrada (Gelman, $0.45 \mu \mathrm{m}$ ) usando resina Chelex-100 en forma amoniacal (Riley y Taylor, 1968; Abdullah et al., 1976) y determinados con un espectrofotómetro de absorción atómica $\mathrm{Va}$ rian 2000 . Todos los reactivos fueron preparados con agua destilada desionizada, de la cual los metales traza fueron atrapados con una columna, $10 \times 1 \mathrm{~cm}$, Chelex-100. Los ácidos fueron redestilados en cuarzo y el amonia fue preparado por destilación isotérmica en teflón. Para concentar los metales traza se utilizaron columnas Chelex-100 de $1 \mathrm{~cm}$ de diámetro y $5 \mathrm{~cm}$ de longitud; se exáminó el efecto de la elevada fuerza iónica sobre la eficiencia aparente de la columna, introduciendo el efluente de cada columna en una segunda columna, la cual fue también subsecuentemente eluida para determinación de metales traza. En la mayoría de los casos el $80 \%$ del total de metales disueltos fue retenido en la primera columna, descartándose los resultados cuando la retención fue inferior al $60 \%$ como en el caso de clorinidades superiores a $140 \%$ oo (donde el $\mathrm{pH}$ de la laguna fue también frecuentemente bajo).

Los blancos para filtros Gelman prelavados fueron estimados filtrando lentamente dos alícuotas (10 l cada una) de una muestra de agua oceánica a trạvés de cinco y 15 filtros, respectivamente, determinándose los metales traza por la técnica mencionada anteriormente. Los blancos de filtros fueron bajos totalmente (requiriéndose generalmente correc- 
will be referred to as "easily leachable" trace metals. In the case of high salt content sediments, the leachate was neutralized, filtered, diluted to $100 \mathrm{ml}$ and then passed through a Chelex-100 column for separation of trace metals. The filter was washed and digested with $2 \mathrm{M} \mathrm{HNO}_{3}$ and the metal content of the combined eluate/filter digest was determined.

\section{Laboratory radiochemical experiments}

In order to examine the behaviour of trace metals in hypersaline waters in the absence and presence of suspended sediments, two series of experiments were conducted. In the first series, spiked 21 batches of filtered $(0.45 \mu \mathrm{m}$ Millipore) Mediterranean seawater were evaporated in magnetically stirred polythene tanks within a continuously ventilated fume cupboard at $25 \pm 3^{\circ} \mathrm{C}$. Three identical tanks were employed, one of which was tightly covered to limit evaporation and thus serve as a continuous reference in order to evaluate metal sorption to the tank walls. The tracers employed (with initial activities and stable carrier concentrations) were: ${ }^{57} \mathrm{Co}\left(24 \mathrm{~Bq} . \mathrm{g}^{-1}\right.$, $0.3 \mathrm{ng}^{-1}$ ); ${ }^{54} \mathrm{Mn}$ (11.8 Bq.g-1, 0.23 ng. $\mathrm{g}^{-1}$ ) and $63 \mathrm{Ni}\left(20\right.$ Bq. ${ }^{-1}, 0.5$ ng.g $\left.{ }^{-1}\right)$. Approximately $5 \mathrm{ml}$ samples were withdrawn from each tank daily and filtered through $0.45 \mu \mathrm{m}$ membrane filters into preweighed plastic scintillation vials and weighed. The filters were washed by filtering about $10 \mathrm{ml}$ of distilled water which was discarded. Any carbonate coprecipitate separated was then dissolved and collected by gradually filtering about $10 \mathrm{ml}$ of $\mathrm{IM} \mathrm{HCl}$ into a second scintillation vial. Measurements of ${ }^{57} \mathrm{Co}$ and ${ }^{54} \mathrm{Mn}$ activity were made by gamma spectrometry using a $\mathrm{NaI}(\mathrm{Tl})$ well crystal. Measurement of $63 \mathrm{Ni}$ was performed by liquid scintillation counting following the addition of $15 \mathrm{ml}$ "Insta-gel" cocktail to each vial. Results were corrected for recoil electrons from the gamma emitters employed. High salinity samples were diluted prior to the addition of cocktail. A second sample was withdrawn from each tank for chlorinity and alkalinity determinations by semi-micro versions of the methods previously described.

For the second series of tank experiments, the distribution of tracers between hypersaline waters and suspended sediments ciones inferiores al $10 \%$ en la concentración final de metales traza) como recientemente ha sido denotado por Bewers et al. (1985).

Las muestras de sedimentos fueron secadas a $80^{\circ} \mathrm{C}$ y digeridas con $\mathrm{HNO}_{3} \quad 2 \mathrm{M}$ por 12 horas en recipientes de teflón previamente a las determinaciones de metales traza por espectrofotometría de absorción atómica. Esta fracción de metales traza será referida como "fácilmente extraible". En el caso de sedimentos con elevado contenido de sal, el extracto fue neutralizado, filtrado, diluido a $100 \mathrm{ml}$ y pasado a través de una columna Chelex-100 para separación de metales traza. El filtro fue lavado y digerido con $\mathrm{HNO}_{3} 2 \mathrm{M}$ $y$ el contenido de metales traza determinado, combinando el contenido del filtro digerido y del eluato.

\section{Experimentos radioquímicos en laboratorio}

Para examinar el comportamiento de metales traza en aguas hipersalinas con y sin presencia de sedimentos suspendidos, dos series de experimentos fueron realizados. En la primer serie, dos litros de agua de mar filtrada (Millipore, $0.45 \mu \mathrm{m}$ ) y marcada del Mediterráneo fueron evaporados en tanques de polietileno agitados magnéticamente con un evaporador ventilado continuamente a $25 \pm 30^{\circ} \mathrm{C}$. Se emplearon tres tanques idénticos, uno de los cuales, fue cerrado herméticamente para limitar la evaporación, y utilizarlo como referencia continua para evaluár la sorción de metales a las paredes del tanque. Los trazadores utilizados (con actividad inicial y concentración estable de acarreador) fueron: ${ }^{57} \mathrm{Co}\left(24\right.$ Bq. ${ }^{-1}, 0.3$ ng.g $\left.{ }^{-1}\right) ;{ }^{54} \mathrm{Mn}$ (11.8 Bq.g $\mathrm{g}^{-1}, 0.23 \mathrm{ng} \cdot \mathrm{g}^{-1}$ ) y ${ }^{63} \mathrm{Ni}\left(20 \mathrm{~Bq} \cdot \mathrm{g}^{-1}\right.$, $0.5 \mathrm{ng} . \mathrm{g}^{-1}$ ). Se tomaron aproximadamente $5 \mathrm{ml}$ de muestra diariamente de cada tanque, se filtraron a través de filtros de membrana, $0.45 \mu \mathrm{m}, \mathrm{y}$ se pesaron en frascos de centelleo de plástico prepesados. Los filtros fueron lavados, filtrando $10 \mathrm{ml}$ de agua destilada, la cual fue descartada. Cualquier coprecipitado de carbonato fue separado, colectado y disuelto filtrando gradualmente cerca de $10 \mathrm{ml}$ de $\mathrm{HCl} 1 \mathrm{M}$ en un segundo frasco de centelleo. Las mediciones de actividad de ${ }^{57} \mathrm{Co}$ y ${ }^{54} \mathrm{Mn}$ se hicieron mediante espectrometría gamma usando un cristal' $\mathrm{NaI}$ (Tl). Las mediciones de ${ }^{63} \mathrm{Ni}$ fueron realizadas en un contador de centelleo líquido, agregando $15 \mathrm{ml}$ de coctel "Insta-gel" a cada frasco. Los resultados 
was measured whilst maintaining either a constant $\mathrm{Cl}^{-}$/sediment concentration ratio or a constant sediment concentration in suspension. A homogenized coastal sediment (principally fine quartz, calcite and chlorite) from the Gulf of Mexico was used for this purpose. Preliminary experiments were conducted in order to measure the uptake kinetics of $57 \mathrm{Co}$ and $54 \mathrm{Mn}$ by periodically filtering weighed (about $5 \mathrm{~g}$ ) aliquots from mechanically shaken spiked $100 \mathrm{ml}$ suspensions of $2 \mathrm{mg} \mathrm{ml}^{-1}$ sediment in seawater at $\mathrm{pH} 8 \pm 0.1$ and $25^{\circ} \mathrm{C}$. The aliquots were vacuum filtered through two $0.45 \mu \mathrm{m}$ filters, the upper filter retaining the sediment and the lower one acting as a blank. The three fractions were counted by gamma spectrometry.

For the main experiment, three evaporation tanks were set up as in the previous series. Sediment was added to the first tank (A) to give a suspension with an initial concentration of $2 \mathrm{mg}$ (dry weight) $\mathrm{ml}^{-1}$. The second tank (B) was evaporated without sediment and the third was employed as a control as in the previous run. Samples (about $10 \mathrm{~g}$ ) from each of the three tanks were taken daily and weighed into plastic scintillation vials. To the sample from tank (B), $20 \mathrm{mg}$ of sediment were added. Both samples were shaken to within $80 \%$ of equilibrium (200 hours) and the $\mathrm{pH}$ was determined prior to filtration and gamma spectrometry as above. The chlorinity of the filtrate was also determined.

\section{Data description parameters}

Various parameters are required in order to describe the field and laboratory data. A convenient approach to examine the conservative or nonconservative behaviour of any ion in a hypersaline system is to express the data as a "specific mass ratio" (concentration of the ion/chlorinity). By plotting this ratio against chlorinity, any deviations from conservative behaviour (a horizontal line on the plot) may be observed up to the point where halite is precipitated and chlorinity itself is no longer a conservative property. This approach is employed throughout the present text.

Results of adsorption experiments in natural water/sediment systems are commonly fueron corregidos para electrones de retroceso desde los emisores gamma utilizados. Las muestras de salinidad elevada se diluyeron previamente a la adición del coctel. Una segunda muestra fue colectada de cada tanque para determinar clorinidad y alcalinidad por técnicas semi-micro de los métodos descritos anteriormente.

Para la segunda serie de experimentos, la distribución de trazadores entre aguas hipersalinas y sedimentos suspendidos se determinó manteniendo la razón de concentración $\mathrm{CI}$ / sedimento constante o una concentración de sedimento suspendido constante. Para este propósito se utilizó sedimento costero homogeneizado (principalmente cuarzo, calcita y clorita) del golfo de México. Se realizaron experimentos prehiminares para medir la cinética de fijación de ${ }^{57} \mathrm{Co}$ y ${ }^{54} \mathrm{Mn}$; se tomaron alícuotas filtradas y pesadas (aproximadamente $5 \mathrm{~g}$ ) de una suspensión de $100 \mathrm{ml}$ de agua de mar conteniendo $2 \mathrm{mg} \cdot \mathrm{ml}^{-1}$ de sedimento suspendido marcado y agitando mecánicamente a $\mathrm{pH} 8 \pm 0.1$ y $25^{\circ} \mathrm{C}$. Las alícuotas fueron filtradas al vacío a través de dos filtros, $0.45 \mu \mathrm{m}$ de poro, el filtro superior para retener el sedimento y el inferior actuando únicamente como blanco (Duursma y Bosch, 1979). Las tres fracciones fueron contadas por espectrometría gamma.

Para el experimento principal, tres tanques de evaporación fueron preparados como en los experimentos previos. El sedimento fue agregado al primer tanque (A) para tener una suspensión con concentración inicial de $2 \mathrm{mg} \cdot \mathrm{ml}^{-1}$ (peso seco); el segundo tanque (B) evaporado sin sedimento y el tercero utilizado como control. De cada uno de los tres tanques se tomaron muestras $(10 \mathrm{~g})$ diariamente y pesadas en frascos de centelleo de plástico. A la muestra del tanque $B$, se le agregaron $20 \mathrm{mg}$ de sedimento; ambas muestras fueron agitadas para lograr un equilibrio de $80 \%$ (200 horas) y el $\mathrm{pH}$ se determinó previamente a la filtración y a la espectrometria gamma. La clorinidad del filtrado también fue determinada.

\section{Descripción de parámetros}

Varios parámetros son requeridos para describir los datos de campo y laboratorio. Un planteamiento conveniente para examinar el comportameinto no conservativo o conservativo de cualquier ion en un sistema hipersalino es expresar los datos como razón de masa 
expressed in terms of $D^{\prime}$, the apparent steady-state distribution coefficient, específica (concentración del ion/clorinidad). Graficando esta razón con respecto a la clorinidad, cualquier desviación del comportamiento conservativo (una línea horizontal sobre el gráfico) puede observarse arriba del punto donde la halita es precipitada y la clorinidad en sí misma, ya no es una propiedad conservativa. Esta suposición es utilizada a través del presente texto.

Los resultados de experimentos de absorción en sistemas naturales sedimento/agua son comúnmente expresados en términos del coeficiente de distribución aparente en estado estable $D^{\prime}$,

$$
D^{\prime}=\{M\}_{s} /[M]_{w}
$$

where $\{M\}_{\mathrm{S}}$ and $[M]_{w}$ are the adsorbed metal concentrations in the solid and aqueous phases (Duursma and Hoede, 1967) expressed in terms of moles of metal per unit weight of the medium (following the scheme adopted by IAEA, 1985, which avoids the litre/kg units used by many authors). The apparent coefficient $D^{\prime}$ is employed here as it is difficult to fully test the assumption of perfect isotope dilution. Though conceptually similar, the term $\mathrm{Kd}$ is avoided here for experimental data.

It is important to emphasize that $D^{\prime}$ is not a true equilibrium constant and varies with the nature and concentration of surface sites for adsorption (and hence concentration of particulate matter in suspension, its surface composition and granulometry), the major ion composition of the medium and that of free protons (competing for individual sites) ( $\mathrm{Li}$ et al., 1984). This latter factor often dominates the regulation of adsorption and has been extensively studied and modelled for single mineral phases (see, for example, Davis and Leckie, 1978). Both an increase in the concentration of particulate matter and ionic strength of the medium tends to lower $D^{\prime}$ (Aston and Duursma, 1974; Di Toro et al., 1986).

For the simple reversible adsorption of a cation $(M)$ on a single mineral phase site (MeO-) from which a major cation $(A)$ or $\mathrm{H}^{+}$ is displaced, donde $\{M\}_{s}$ y $[M]_{w}$ son las concentraciones de metal adsorbido en las fases sólida y acuosa (Duursma y Hoede, 1967) expresada en moles de metal por unidad de peso del medio (siguiendo el esquema adoptado por IAEA, 1985; el cual evita las unidades litro $/ \mathrm{kg}$, usadas por muchos autores). El coeficiente aparente $D^{\prime}$, es utilizado aqui, dada la dificultad de asumir completamente pruebas de dilución isotópica perfecta. Aunque, similar conceptualmente, el término Kd es evitado aquí para datos experimentales.

Es importante enfatizar que $D^{\prime}$ no es una constante de equilibrio verdadera y varía con la concentración y naturaleza de sitios superficiales para absorción ( $y$ por consiguiente de la concentración del material suspendido, su composición superficial y granulometría), la composición del ion más abundante del medio y de protones libres (compitiendo por sitios individuales) (Li et al., 1984). Este último factor domina y regula la adsorción frecuentemente; ha sido estudiado $y$ modelado extensamente para fases minerales sencillas (ver, por ejemplo, Davis y Leckie, 1978). Un incremento en la concentración de fuerza iónica y material particulado del medio, tiende a decrecer $D^{\prime}$ (Aston y Duursma, 1974; Di Toro et al., 1986).

Para la adsorción reversible simple de un catión $(M)$ sobre un sitio particular de fase mineral ( $\mathrm{MeO}$-) desde el cual un catión más abundante $(A) \mathrm{o}^{+}$es desplazado, 


$$
M^{z}+M e O-A_{x}=M e O-M^{z-x}+x A
$$

from Li et al. (1984), it can be shown that the apparent equilibrium constant, de Li et al. (1984), puede demostrarse que la constante de equilibrio aparente,

$$
K_{a p}=[A]^{x} D^{\prime} /\left\{\operatorname{MeO} A_{x}\right\}
$$

(where [ ] are concentrations in moles/g solution and \{\} in moles/g of the solid phase). In order to apply this equilibrium constant, a detailed knowledge is required of the surface chemistry of each of the mineral phases present and the relative importance of the major cations (such as $\mathbf{M g}^{+2}$ ). There are other drawbacks limiting the wide application of $K_{a p}$ (or $D^{\prime}$ ), such as non-reversible adsorption (Di Toro et al., 1986), the formation of new surface coating by the autocatalytic oxidation of $\mathrm{Mn}$ (II) and Co(II), (Nyffler et al., 1984), the probability of more than one surface stoichiometric reaction (Davis and Leckie, 1978) and the aggregation or nucleation of particulate radioisotope species (Aston and Duursma, 1974).

Even if these factors are ignored, a further practical problem arises. The addition of a very small amount of carrier-free tracer will cause minimal perturbation of the equilibrium expressed in (3) and its distribution should reflect $D^{\prime}$ (Li et al., 1984). If, however, the equilibrium is perturbed, perhaps exceeding the cation exchange capacity (Stumm and Morgan, 1981) of the solid phase, then from expression (1) it follows that $D^{\prime}$ will be lowered as a function of the excess radiotracer in solution (see, for example, Aston and Duursma, 1974). In laboratory experiments, $D^{\prime}$ should thus be used with utmost caution as it is often an artifact of experimental design and may not reflect the chemical processes studied.

An additional descriptive parameter for the present experiment is the mole fraction of occupied surface adsorption sites (at steady-state). (donde [] es concentración en moles/g de solución y \{\} moles/g de fase sólida).

Para aplicar esta constante de equilibrio, se requiere un conocimiento detallado de la química superficial de cada una de las fases minerales presentes y la importancia relativa de los cationes más abundantes (tal como $\mathrm{Mg}+2$ ). Existen otras desventajas que limitan la aplicación amplia de $K_{a p}\left(o D^{\prime}\right)$, tal como adsorción no-reversible (Di Toro et al., 1986), la formación de nuevas superficies por la oxidación autocatalítica de Mn (II) y Co (II), (Nyffler et al, 1984), la probabilidad de más de una reacción estequiométrica superficial (Davis y Leckie, 1978) y la agregación o nucleación de especies radioisotópicas particuladas (Aston y Duursma, 1974).

Incluso, si estos factores son ignorados, resultan otros problemas prácticos. La adición de una cantidad muy pequeña de trazador libre de acarreador causará perturbación mínima del equilibrio expresado en (3) y su distribución podría reflejar $D^{\prime}$ (Li et al., 1984). Sin embargo, si el equilibrio es perturbado, excediendo la capacidad de intercambio catiónico de la fase sólida (Stumm y Morgan, 1981), entonces de la expresión (1), $D^{\prime}$ disminuirá como una función del radiotrazador en exceso en la solución (ver, por ejemplo, Aston y Duursma, 1974). En experimentos de laboratorio, $D^{\prime}$ debería ser utilizada con sumo cuidado dado que es frecuentemente un artefacto de diseño experimental y no puede reflejar los procesos químicos estudiados.

Un parámetro descriptivo adicional para el experimento es la fracción mol, de sitios de adsorción superficial ocupados (en estado estable).

$$
X_{M \bullet O-M}=\{M e O-M\} /(\{M e O-A\}+\{M e O-M\})
$$


Mee and Osuna-López: Trace metal chemistry of a tropical hypersaline basin

This is simply the proportion of exchangeable sites occupied and avoids some of the pitfalls associated with $D^{\prime}$. In the present experiment, the number of exchangeable sites was not known. However, for a given sediment of fixed surface area and mineralogy, $(\{M e O-A\}+\{M e O-M\})$ should be constant. For an isotope dilution experiment where labelled metal $M^{*}$ is in equilibrium:
Esto es simplemente la proporción de sitios ocupados intercambiables y algunos de los evitados asociados con $D^{\prime}$. En el experimento presente, el número de sitios intercambiables no se determinó. Sin embargo, para un sedimento dado de mineralogía y área superficial fija, $(\{M e O-A\}+\{M e O-M\})$ puede ser constante. Para una dilución isotópica donde el metal marcado, $M^{*}$, está en equilibrio:

$$
\left\{M^{*}\right\}=X_{N e O-N} Q_{s}
$$

(where $Q_{\mathrm{s}}$ is a proportionality constant). The $\left\{M^{*}\right\}$ is an intensive parameter which, together with $D^{\prime}$, will be employed to describe the results of the present experiment.

\section{RESULTS}

\section{Field studies}

The horizontal chlorinity gradient for the lagoon is shown in Figure 1. Observed chlorinities ranged from slightly above seawater $(21.70 \%$ oo $)$ to sodium chloride saturation (about $160 \%$ oo). The distribution of $\mathrm{pH}$ and alkalinity is shown in Figure $2 \mathrm{a}$, and $2 \mathrm{~b}$ (as specific alkalinity) together with values for laboratory tank experiments in the presence and absence of solid aragonite recalculated from Lazar et al. (1983). The present data falls between these two experimental extremes.

The distribution of dissolved trace metals in the lagoon is shown in Table 1. Concentrations per unit mass were calculated from original volume-based data using the chlorinity-salinity equations of Fernández et al. (1982). Initial trace metal concentrations (Cl 21-23\% $/ 00$ ) were typical of contaminated coastal waters or lagoons (see, for example, Brian, 1976; de Luca et al,, 1986). The non-conservative behaviour of trace metals is clearly seen in Figure 3 where specific mass ratios are plotted. A general pattern is evident in which there is an initial loss of most metals from the system with increasing chlorinity up to $40-50 \%$ oo (stage 1), followed by a period of relatively conservative behaviour at higher chlorinities, interrupted by a sharp increase in some metal concentrations (stage II) especially during the first survey where maximum concentrations were found at about (donde $Q_{\mathrm{s}}$ es una constante de proporcionalidad). La $\left\{M^{*}\right\}$ es un parámetro intensivo el cual, junto con $D^{\prime}$, será empleado para describir los resultados del experimento presente.

\section{RESULTADOS}

\section{Estudios de campo}

En la Figura 1, se ilustra el gradiente horizontal de clorinidad de la laguna. El intervalo de clorinidad varía desde ligeramente superior a la del agua de mar $(21.70 \%$ oo) hasta saturación del cloruro de sodio (cerca de $160 \%$ oo). La distribución de alcalinidad y $\mathrm{pH}$ se muestra en las Figuras $2 a$ y $2 b$ (como alcalinidad específica) junto con los valores de los experimentos de laboratorio en ausencia y presencia de aragonita sólida recalculada de Lazar et al. (1983). Los datos obtenidos caen entre estos dos extremos experimentales.

La distribución de metales traza disueltos en la laguna se muestra en la Tabla 1. Las concentraciones por unidad de masa fueron calculadas del volumen original con base en los datos, utilizando las ecuaciones salinidad-clorinidad de Fernández et al. (1982). Las concentraciones iniciales de metales traza $(\mathrm{Cl} \%$ oo, 21-23) fueron típicas de aguas costeras o lagunas contaminadas (ver, por ejemplo, Brian 1976; de Luca et al., 1986). El comportamiento no conservativo de metales se observa claramente en la Figura 3 donde se ilustran las razones de masa específica. Un modelo general en el cual existe una pérdida inicial de la mayoría de metales desde el sistema con el incremento de clorinidad hasta $40-50 \%$ oo (estado I), seguido por un período de comportamiento relativamente conservativo a clorinidades superiores, interrumpido por un 


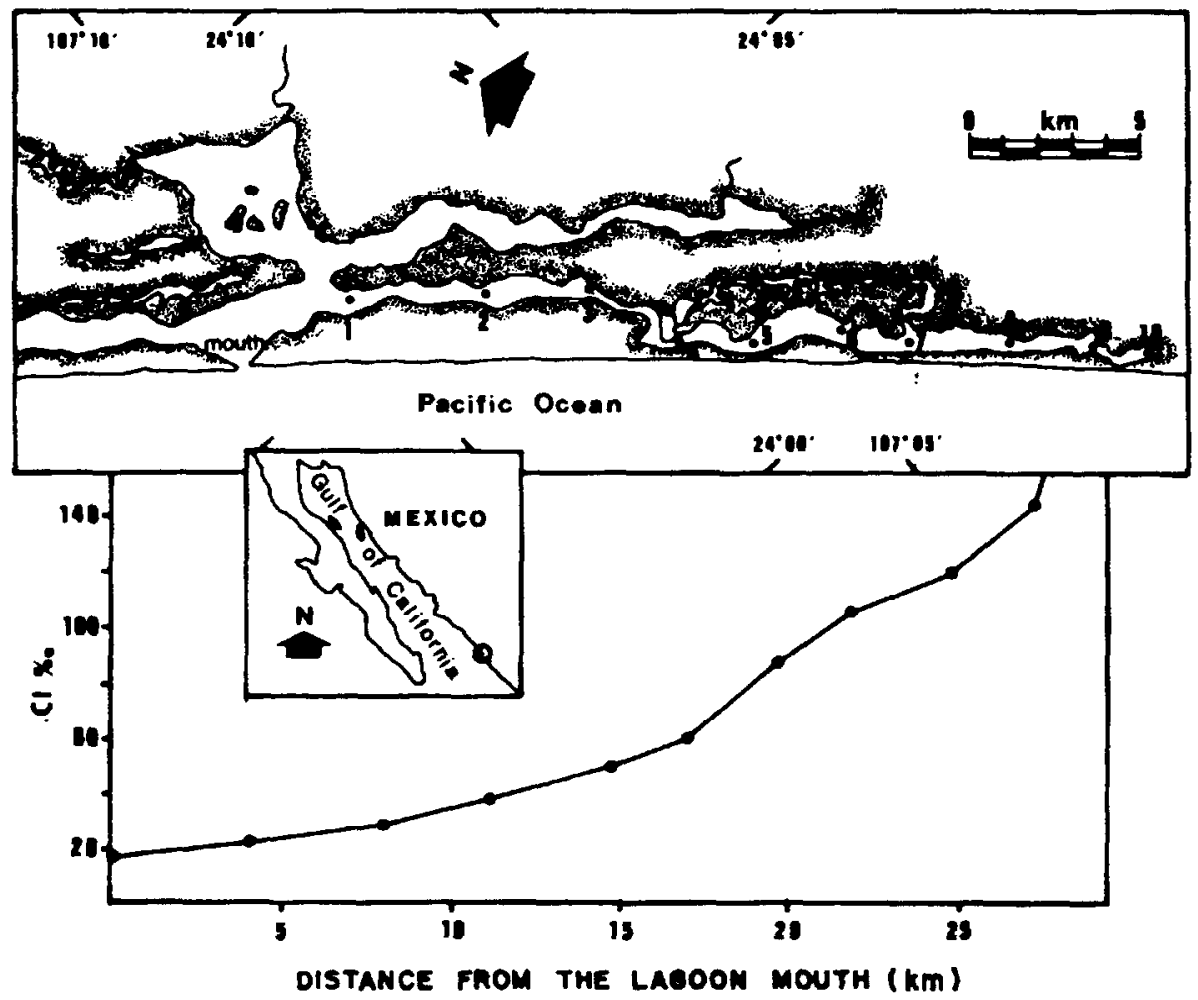

Figure 1. Map of Ceuta lagoon and distribution of chlorinity during first survey. (Collection sites, $\bullet$.)

Figura 1. Mapa de laguna Ceuta y distribución de clorinidad durante el primer muestreo (sitios de muestreo, $\bullet$ ).

$\mathrm{Cl}=105 \%$ oo (see Table 1 ). It is apparent that this increase represents an additional source to the system, given that the individual metal: $\mathrm{Cl} \%$ oo ratio often exceeds that of the source seawater (particularly in the case of $\mathrm{Mn}$ and $\mathrm{Zn})$.

The concentration of easily leachable trace metals in sediments is illustrated in Figure 4. In order to simplify the considerable volume of data generated, only values for the top two sediment sections of each core are illustrated. For convenience, the data are plotted against chlorinity at the time of sampling but this does not necessarily represent the long-term mean of chlorinity at each point. The trace metal levels are in general agreement with those measured in other lagoons in arid or tropical areas (see, for example, Bertine and Schug, 1981; de Luca et incremento abrupto en la concentración de algunos metales (estado II), es evidente, especialmente durante el primer muestreo, en el cual, se encontraron concentraciones máximas de cerca de $105 \%$ oo de clorinidad (ver Tabla 1). Aparentemente, este incremento representa una fuente adicional al sistema, dado que la razón metal individual: clorinidad frecuentemente excede a la del agua de mar (particularmente en el caso de Mn y Zn).

La concentración en sedimentos de metales traza "fácilmente extraibles" se ilustra en la Figura 4. Para simplificar el volumen considerable de datos generados solamente se ilustran los valores de las dos secciones superficiales de sedimento. Por conveniencia, los datos son graficados con respecto a la clorinidad al tiempo de muestreo, pero representa necesariamente la clorinidad media a 

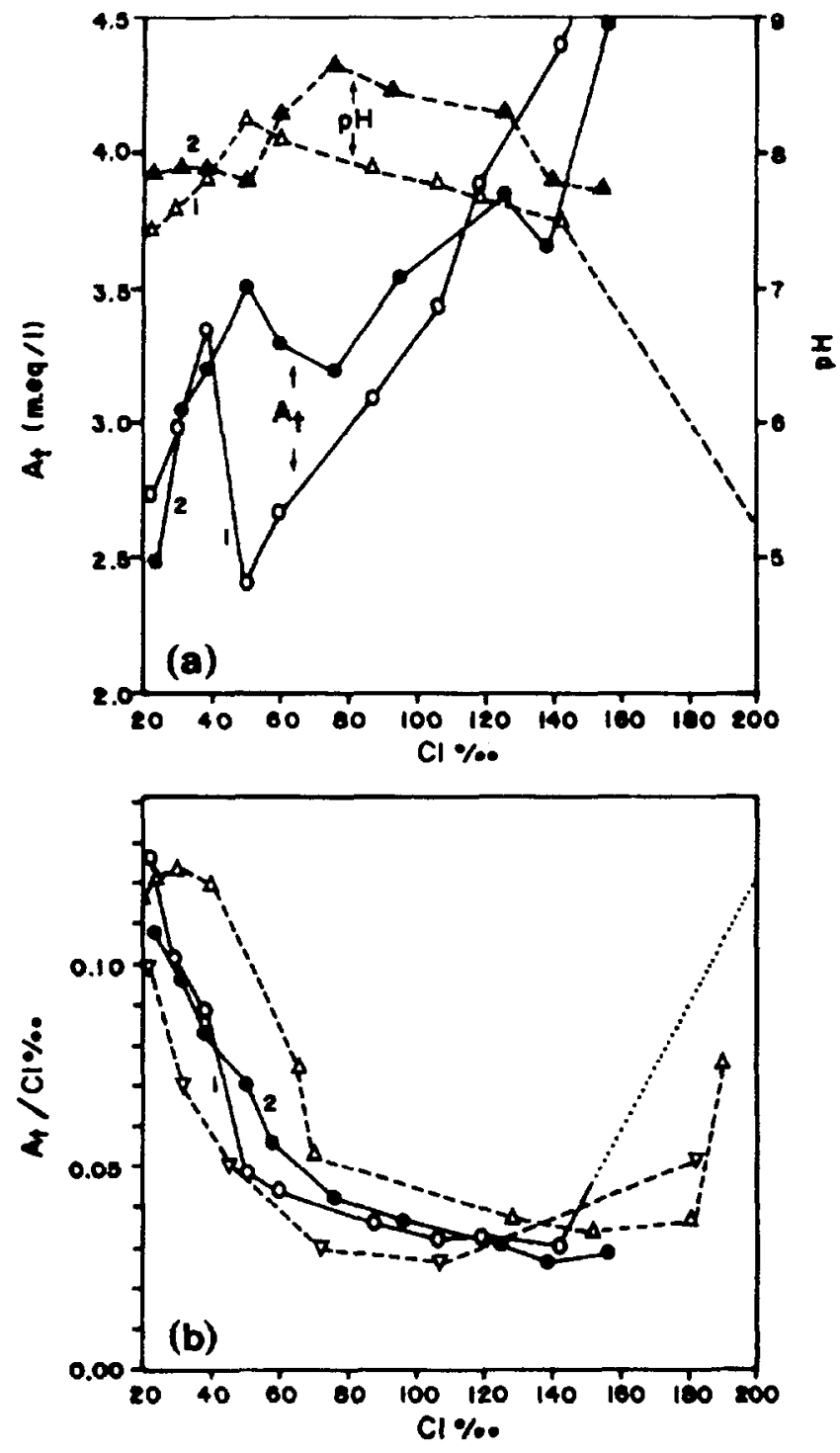

Figure 2a. Distribution of total alkalinity (At) and $\mathrm{pH}$ in the first (1) and second (2) surveys. Figura 2a. Distribución de alcalinidad total (At) y pH en el primero (1) y segundo (2) muestreo.

Figure 2b. Comparison of the specific alkalinity distributions found in the first (1) and second (2) surveys with the experimental data of Lazar et al. (1983) in the presence (4) and absence ( $\nabla)$ of solid aragonite.

Figura 2b. Comparación de la distribución de alcalinidad específica durante el primero (1) y segundo (2) muestreo con los datos experimentales de Lazar et al. (1983) en presencia (4) y ausencia $(\nabla)$ de aragonita sólida. 
Table 1. Concentration of trace metals in surface waters of the Ceuta lagoon.

Tabla 1. Concentración de metales traza en aguas superficiales de la laguna Ceuta.

\begin{tabular}{|c|c|c|c|c|c|c|c|}
\hline \multirow[t]{2}{*}{ Station } & \multirow{2}{*}{$\begin{array}{c}\text { Chlorinity } \\
\%\end{array}$} & \multicolumn{6}{|c|}{ Concentration $\left(\mu \mathrm{g} \mathrm{kg}^{-1}\right)$} \\
\hline & & $\mathrm{Cu}$ & $\mathrm{Fe}$ & $\mathrm{Mn}$ & $\mathrm{Ni}$ & $\mathrm{Pb}$ & $\mathrm{Zn}$ \\
\hline \multicolumn{8}{|c|}{19 May 80} \\
\hline 1 & 21.7 & 1.1 & 1.7 & 3.0 & 1.1 & 1.7 & 5.9 \\
\hline 2 & 29.0 & 0.8 & 2.6 & 1.4 & 1.3 & 1.0 & 5.1 \\
\hline 3 & 37.8 & 1.0 & 2.3 & 0.4 & 1.2 & 0.6 & 10.5 \\
\hline 4 & 49.8 & 1.0 & 0.6 & 0.7 & 1.6 & 1.3 & 13.1 \\
\hline 5 & 60.1 & 1.2 & 2.3 & 1.1 & 1.1 & 2.8 & 16.6 \\
\hline 6 & 86.7 & 1.0 & 3.1 & 13.8 & 1.9 & 4.8 & 84.9 \\
\hline 7 & 106.0 & 1.8 & 5.0 & 194.5 & 3.4 & 9.3 & 163.0 \\
\hline 8 & 118.3 & 1.0 & 1.5 & 150.2 & 0.9 & 2.4 & 5.7 \\
\hline 9 & 142.5 & 1.6 & 1.7 & 224.2 & 0.7 & 1.5 & 9.2 \\
\hline \multicolumn{8}{|l|}{11 July 80} \\
\hline 1 & 23.0 & 0.6 & 3.5 & 1.1 & 1.1 & 2.4 & 18.3 \\
\hline 2 & 31.6 & 0.7 & 0.6 & 0.6 & 1.0 & 1.1 & 12.8 \\
\hline 3 & 38.0 & 0.4 & 1.0 & 0.3 & 0.7 & 1.4 & 3.7 \\
\hline 4 & 59.1 & 0.8 & .2 .0 & 0.1 & 1.2 & 1.4 & 12.3 \\
\hline 5 & 76.2 & 1.2 & 2.3 & 2.5 & 0.8 & 1.8 & 4.0 \\
\hline 6 & 94.7 & 1.1 & 6.2 & 0.3 & 1.1 & 1.6 & 48.4 \\
\hline 7 & 125.5 & 1.4 & 1.4 & 65.6 & 0.7 & 1.6 & 37.8 \\
\hline 8 & 138.1 & 1.3 & 1.9 & 100.6 & 1.0 & 1.7 & 13.4 \\
\hline 9 & 156.0 & 0.7 & 1.7 & 16.1 & 0.3 & ND & 49.2 \\
\hline
\end{tabular}

al., 1986). Concentration maxima were observed at stations 4 or $5(\mathrm{Cl}=50-60 \%$ oo $)$ in all cases. Surface minima were observed at stations 9 and $10(\mathrm{Cl}=140 \%$ oo $)$ where lagoon sediments were covered by a $1-2 \mathrm{~cm}$ layer of cvaporites. Metal concentrations generally increased with depth except at stations 4 (all metals) and 5 (all except $\mathrm{Mn}, \mathrm{Zn}$ and $\mathrm{Fe}$ ) where a reverse gradient was observed.

\section{Laboratory experiments}

The variation of specific activity of added nuclides (activity per unit weight of seawater: $\mathrm{Cl} / \mathrm{oo}$ ) with chlorinity is shown in Figure 5. These results are corrected for a small (about 12\%) loss of tracer from solution in the control tank within the first 24 hours of the experiment. At least half of this loss was recovered by filtration, possibly indicating loss to any small biomass present or oxyhydroxide largo plazo en cada punto. Los niveles de metales traza son concordantes con aquellos determinados en otras lagunas de áreas tropicales o áridas (ver, por ejemplo, Bertine y Shug, 1981; de Luca et al., 1986). Las concentraciones máximas fueron observadas en las estaciones 4 o $5(\mathrm{ClO} / \mathrm{oo}=50-60)$ en todos los casos. El mínimo superficial fue observado en las estaciones 9 y $10(\mathrm{Cl} / \% 0,140)$ donde los sedimentos estuvieron cubiertos por una capa de $1-2 \mathrm{~cm}$ de evaporitas. La concentración de metales generalmente incrementa con la profundidad excepto en las estaciones 4 (todos los metales) y 5 (todos, excepto $\mathrm{Mn}, \mathrm{Zn} \mathrm{y} \mathrm{Fe}$ ) donde, se observó un gradiente inverso.

\section{Experimentos de laboratorio}

La variación de reactividad específica de núclidos agregados (actividad por unidad de peso de agua de mar: $\mathrm{Cl} \%$ oo), con respecto a 

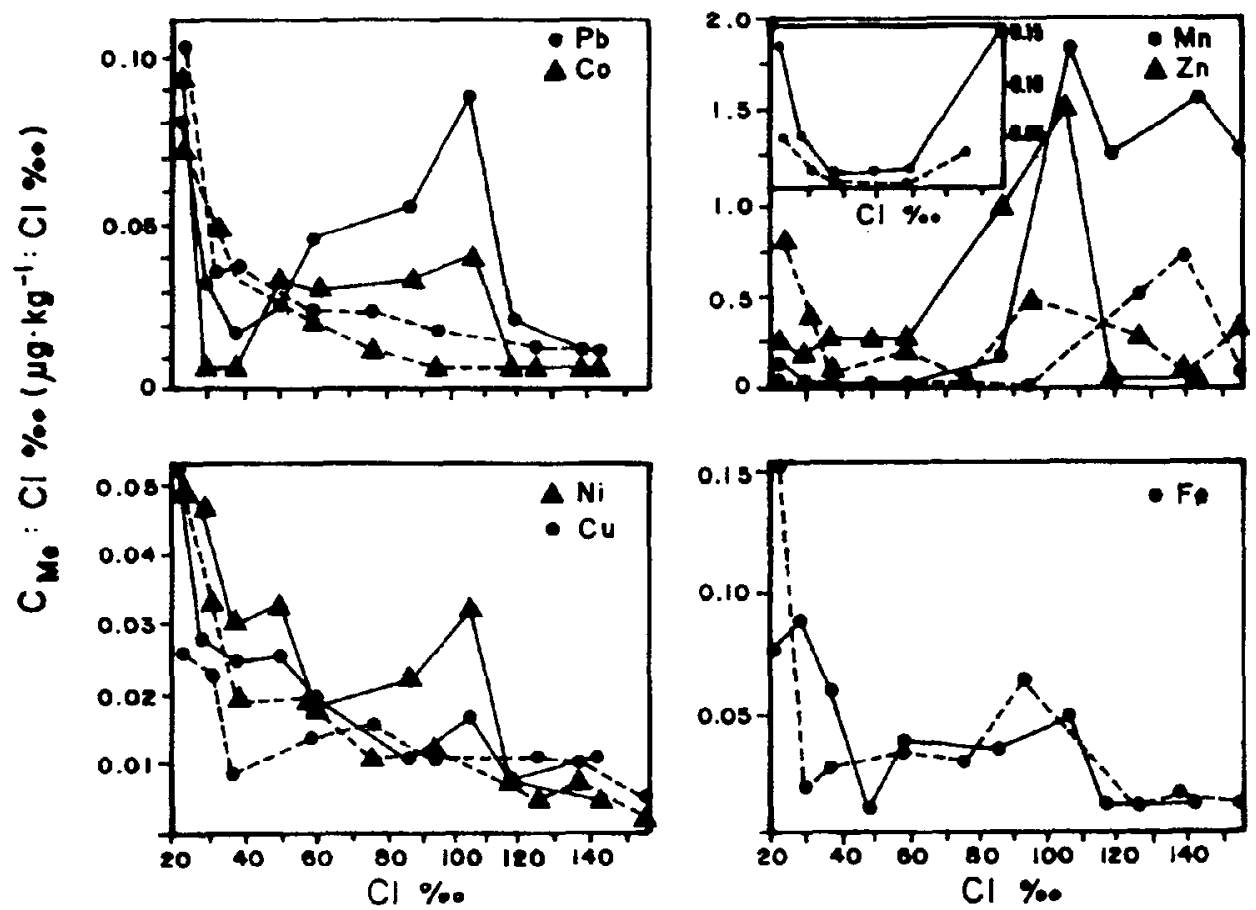

Figure 3. Specific mass ratios of trace metals. Data from the first survey is shown with a continuous line and from the second survey with a pecked line.

Figura 3. Tasas de masa específica de metales traza. Los datos del primer muestreo se presentan con línea continua y del segundo con línea intermitente.

precipitation (reported to be $1-6 \%$ under similar conditions by Fukai and Huynh-Ngoc, 1968). No further losses were observed for the control throughout the experiment. For the evaporation tanks, the soluble acid particulate fraction of each tracer was less than $5 \%$ of that in solution at all times until halite precipitation was observed. Random counting errors did not exceed $2 \%$ (63\% confidence interval). As can be seen from Figure 5, the three tracers behaved conservatively in the chlorinity range $20-155 \%$ oo. Specific alkalinity decreased from 0.13 to $0.04 \mathrm{~m} \mathrm{eq}^{-1}$ : $\mathrm{Cl} \%$ oo as chlorinity increased from $20-65 \%$ oo, illustrating the precipitation of calcium carbonate. The presence of this precipitate in suspension was confirmed by titrating both filtered and unfiltered samples at chlorinity $65 \%$ oo.

Halite precipitation commenced where chlorinity exceeded about 1570/oo. Above this point, the ${ }^{57} \mathrm{Co} / \mathrm{Cl}$ and $63 \mathrm{Ni} / \mathrm{Cl}$ ratios clorinidad se muestra en la Figura 5. Estos resultados están corregidos por una pérdida (cerca del 12\%) de trazador desde la solución en el tanque de control, dentro de las primeras 24 horas del experimento. La mitad de ésta fue recuperada por filtración, indicando posiblemente pérdidas hacia cualquier biomasa pequeña presente $\mathrm{y} / \mathrm{o}$ precipitación de oxi-hidróxidos (bajo condiciones similares se ha publicado que es del $1-6 \%$, Fukai y Huynh-Ngoc, 1968). No se observó ninguna otra pérdida durante el transcurso del experimento. Todo el tiempo, la fracción particulada soluble en ácido de cada trazador fue inferior en un $5 \%$ al de la solución en los tanques de evaporación hasta que ocurrió la precipitación de halita. Los errores de conteo "random" no excedieron el $2 \%$ (intervalo de confianza, $63 \%$ ). Como se observa en la Figura 5, los tres trazadores se comportan conservativamente en el intervalo de clorinidad de $20-155 \%$ oo. La alcalinidad especifica decrece 


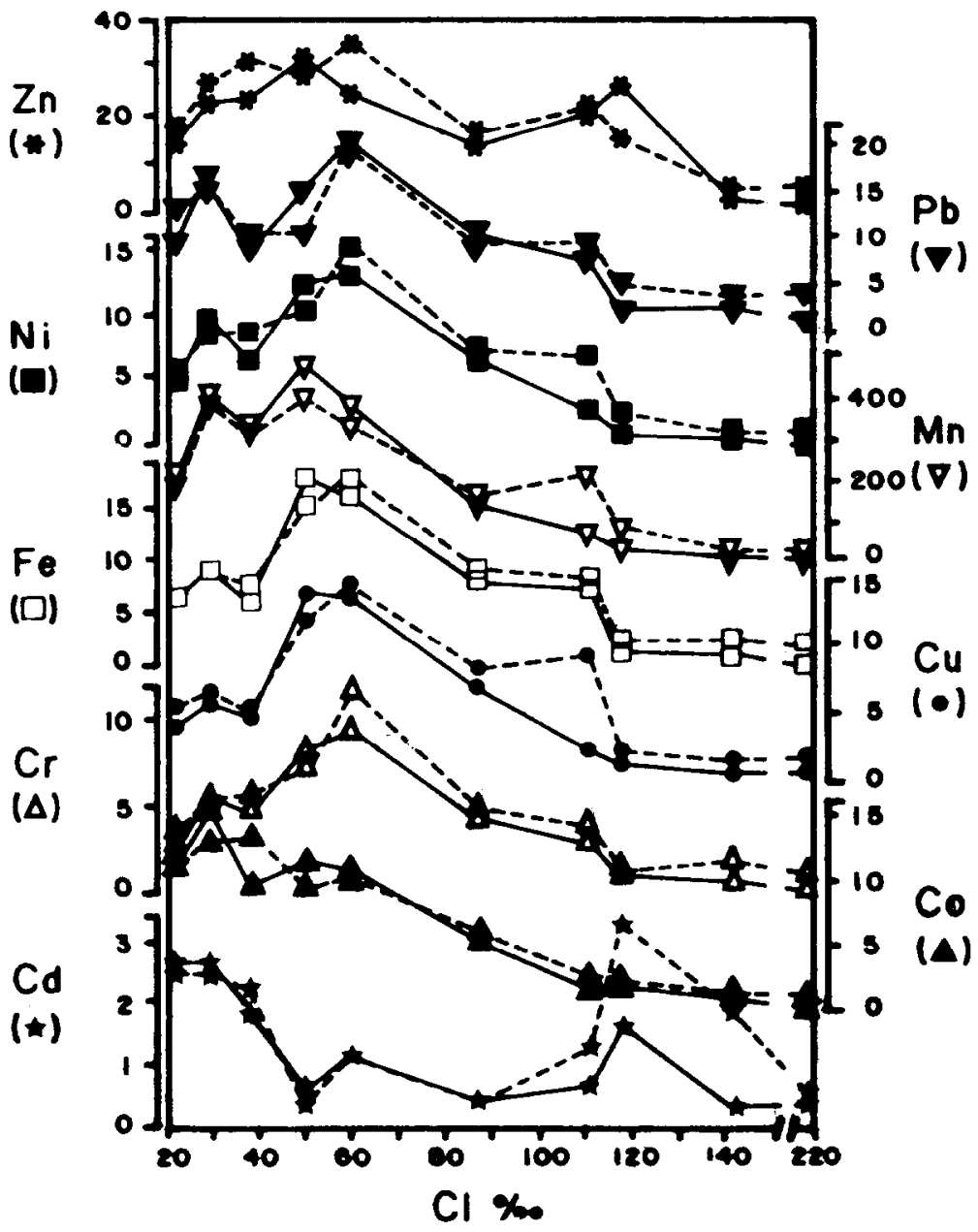

Figure 4. Concentrations of "easily leachable" trace metals in surtace $[(u-0.5 \mathrm{~cm}),(-)]$ and subsurface $[(0.5-1.5 \mathrm{~cm}),(---)]$ sediments. All metals in $\mu \mathrm{g} \cdot \mathrm{g}^{-1}$ (dry weight) except Fe (mg.g ${ }^{-1}$ ).

Figura 4. Concentraciones de metales traza "fácilmente extraibles" en sedimentos superficiales $[(0-0.5 \mathrm{~cm}),(-)]$ y sub-superficiales $[(0.5-1.5 \mathrm{~cm}),(-)]$. Todos los metales en $\mu \mathrm{g} \cdot \mathrm{g}^{-1}$ (peso seco) excepto Fe (mg.g $\left.{ }^{-1}\right)$.

increased sharply and the $54 \mathrm{Mn} / \mathrm{Cl}$ ratio decreased. This illustrates the retention of $\mathrm{Ni}$ and $\mathrm{Co}$ to the last bitters but precipitation of $\mathrm{Mn}$. Analysis of a small sample of orthorhombic salt crystals revealed $\mathrm{Co}, \mathrm{Ni}$ and $\mathrm{Mn}$ activities per unit weight of $\mathrm{Cl}^{-}\left(\mathrm{Bq} \mathrm{g}^{-1}\right)$ of $0.24,0.07$ and 0.45 respectively. In the case of $\mathrm{Mn}$, this value is similar to that of the activity ratio for the original seawater (see Fig. 5) whilst those for $\mathrm{Co}$ and $\mathrm{Ni}$ were considerably de 0.13 a 0.04 meq. $\mathrm{kg}^{-1}$ : $\mathrm{Cl} \%$ oo, mientras que la clorinidad incrementa de $20-65 \%$ oo, ilustrando la precipitación de carbonato de calcio. La presencia de este precipitado en suspensión se confirmó titulando muestras filtradas y sin filtrar a $65 \%$ oo de clorinidad.

La precipitación de halita inició cerca de 1570/oo de clorinidad. Por encima de este punto, la razón ${ }^{57} \mathrm{Co} / \mathrm{Cly}{ }^{63} \mathrm{Ni} / \mathrm{Cl}$ incrementa abruptamente y la razón $54 \mathrm{Mn} / \mathrm{Cl}$ decrece. 


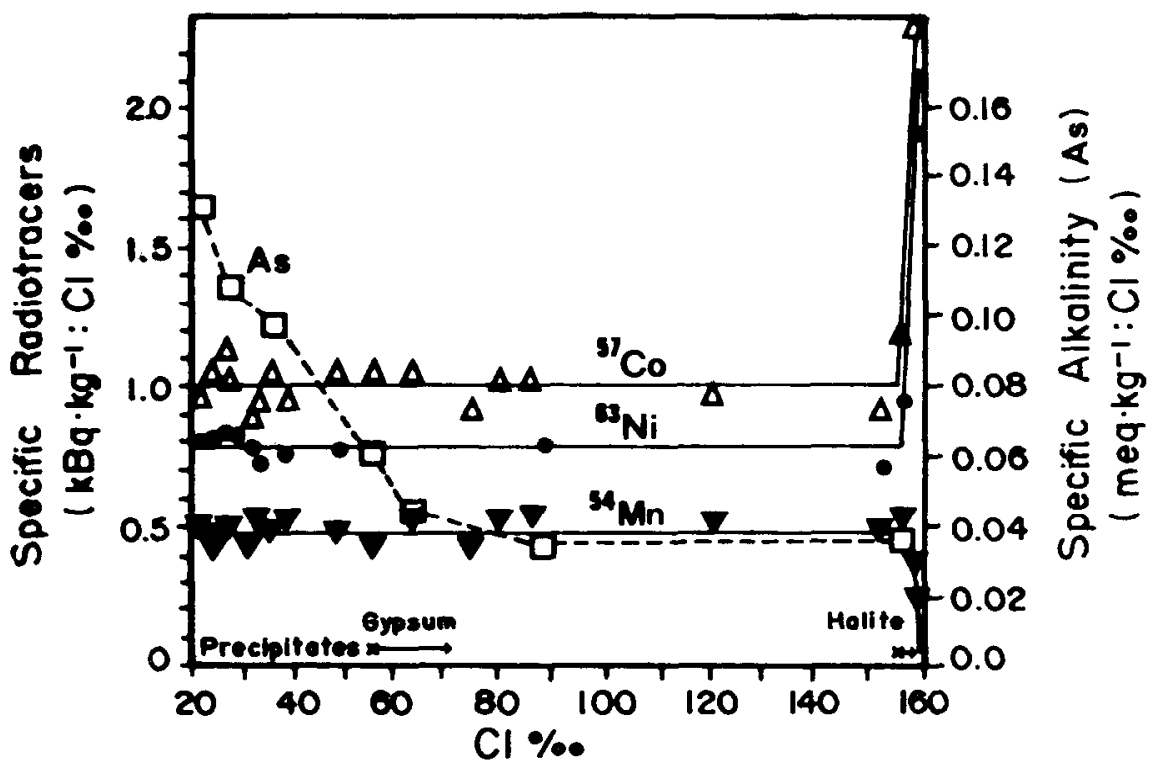

Figure 5. Results of the first evaporation tank experiments. Data are plotted as specific mass rations ( $\mathrm{x}$, initial point of precipitation).

Figura 5. Resultados de los experimentos del primer tanque de evaporación. Datos graficados como tazas de masa específica ( $x$, inicio de la precipitación).

lower, further illustrating the difference in the behaviour of these metals during halite precipitation.

Results of the sediment adsorption experiment are shown in Figure 6. In Figure 6a, the results from both the $A$ (sediment concentration $\left(\mathrm{C}_{\mathrm{S}}\right) / \mathrm{Cl}=$ constant $)$ and $\mathrm{B}\left(\mathrm{C}_{\mathrm{s}}=\right.$ $2 \mathrm{mg} / \mathrm{ml}$ ) evaporation tanks are expressed in terms of $D^{\prime}$. It can be appreciated that a similar general pattern was observed for both experiments. Values of $D^{\prime}$ increased rapidly to a maximum at about $\mathrm{Cl} 260 \%$ oo $\left(45^{\circ} / 00\right.$ in the case of $\mathrm{Mn}$, tank A) and then gradually fell to about $10 \%$ of the maximum at $\mathrm{Cl} 155 \%$ oo. In Figure $6 \mathrm{~b}$, the ratio of occupied active sites, $X_{M e O}-M$ (initial) $/ X_{M e O}-M$ (final) $=$ $\left\{M^{*}\right\}_{\text {(initial) }} /\left\{M^{*}\right\}$ (final) (from equation 5), is plotted with respect to chlorinity. Results for experiment $B$ were generally lower than experiment $A$. The ratio increased sharply in the chlorinity range $20-50 \%$, attaining a maximum at about $45 \% / 00(55 \%$ oo in the case of $\mathrm{Mn}$, tank B). Following this maximum, the ratio steadily decreased in the case of manganese (to $50 \%$ and $30 \%$ of the maximum for tanks $B$ and $A$ respectively) and remained
Esto ilustra la precipitación de $\mathrm{Mn}$ y la retención de $\mathrm{Ni} \mathrm{y} \mathrm{Co} \mathrm{en} \mathrm{la} \mathrm{salmuera} \mathrm{restante.}$ Los análisis de una muestra pequeña de cristales de sal ortorómbica revelan actividades de $\mathrm{Co}$, Ni y $\mathrm{Mn}$, por unidad de peso de $\mathrm{Cl}$ (Bq. ${ }^{-1}$ ) de $0.24,0.07$ y 0.45 , respectivamente. En el caso del $\mathrm{Mn}$, este valor es similar al de la razón de actividad en el agua de mar original (ver figuras), mientras que las de Coy $\mathrm{Ni}$ fueron considerablemente inferiores, mostrando la diferencia en el comportamiento de estos metales durante la precipitación de halita. Los resultados de los experimentos de absorción en sedimento se muestran en la Figura 6. En la Figura 6a, los resultados de los tanques de evaporación, A (concentración de sedimento $\left(\mathrm{C}_{\mathrm{S}}\right) / \mathrm{Cl}=$ constante) y $\mathrm{B}(\mathrm{Cs}=$ $2 \mathrm{mg} / \mathrm{ml}$ ), son expresados en términos de $D^{\prime}$.

Puede apreciarse que un modelogeneral similar se observó en ambos experimentos. Los valores de $D^{\prime}$ incrementan rápidamente hasta un máximo cerca de $\mathrm{Cl}$ 26\% $/ 00$ (45\% $/ 00$ en el caso de $\mathrm{Mn}$, tanque A) y decrece gradualmente hasta $10 \%$ del máximo a $\mathrm{Cl} 155 \%$ oo. En la Figura 6b, la razón de sitios activos ocupados, $X_{M e O} M$ (inicial) $/ X_{M e O}-M$ (final) $=$ 

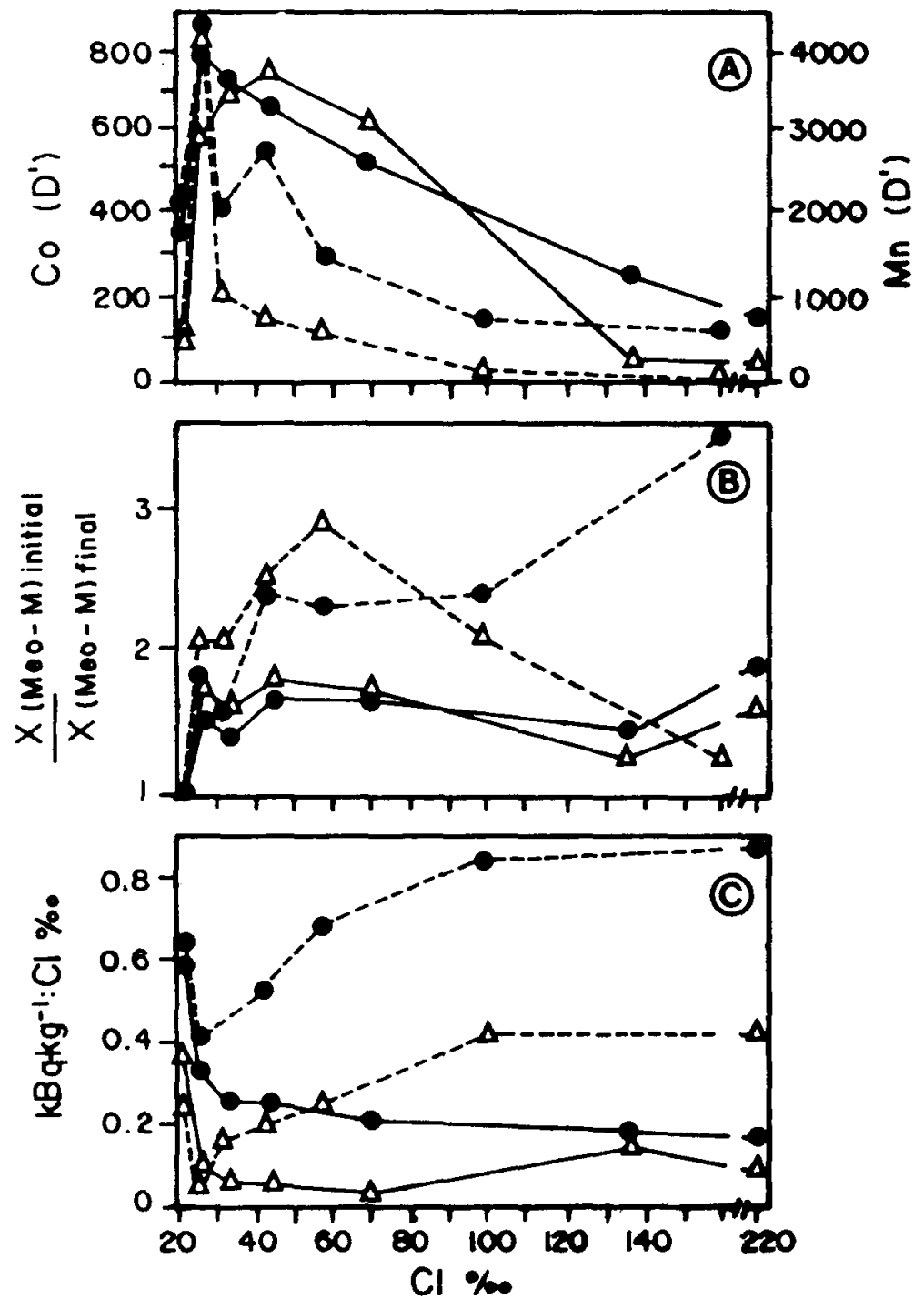

Figure 6. Results of the sediment partition experiments: (A) variation of the apparent distribution constant $D^{\prime}$ with chlorinity, (B) apparent ratio of occupied active adsorption sites, (C) concentration of unadsorbed radiotracers (plotted as specific activity ratios). Experiments, $\mathbf{A}(-)$ and B (---) for cobalt ( $\bullet$ ) and manganese ( $\Delta)$.

Figura 6. Resultados de los experimentos de participación en sedimentos: (A) variación de la constante de distribución aparente $D^{\prime}$ con respecto a la clorinidad, (B) tasa aparente de sitios activos de adsorción ocupados, (C) concentración no adsorbida de radiotrazadores (graficada como tasas de actividad específica). Experimentos, A( $\rightarrow$ y $\mathrm{B}(-)$ para cobalto $(\bullet)$ y manganeso ( $\Delta)$. 


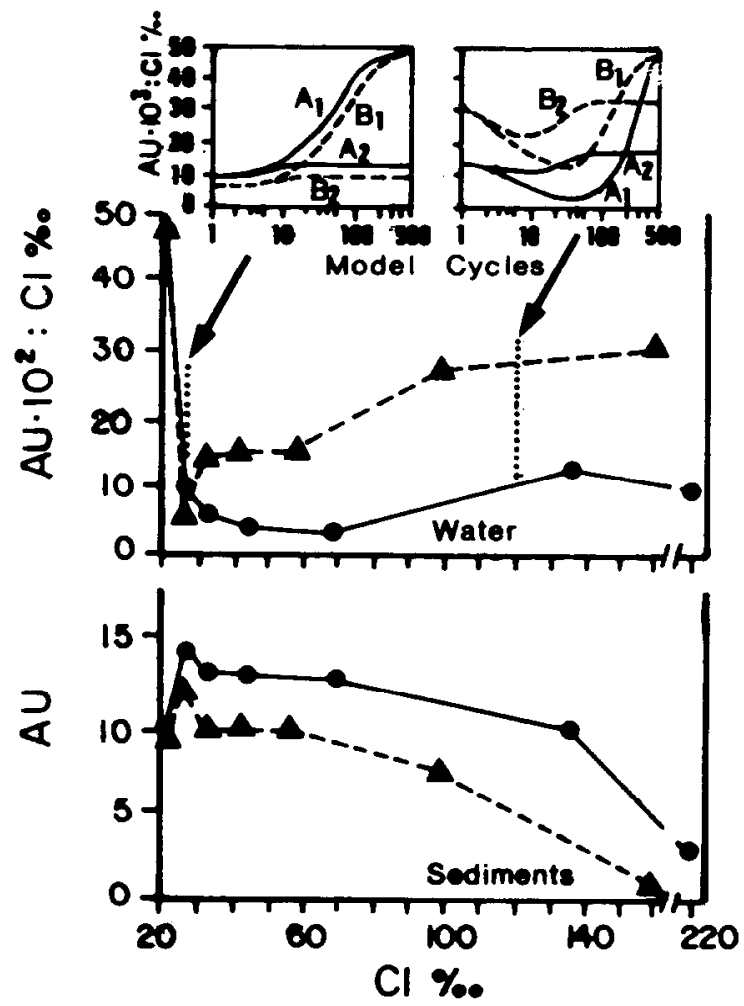

Figure 7. Model simulation of a hypersaline system based on expcrimental values of $D^{\prime}$. The results shown are for Mn using scenario 2 (movement of water and suspended sediments), cycle 2 . Insets show variation of water concentrations at two points in the system as the model is cycled until a steady-state is reached. Experiments, $A(-)$ and $B(---)$, arbitrary units (AU).

Figura 7. Modelo de simulación de un sistema hipersalino basado en valores experimentales de $D^{\prime}$. Se muestran los resultados del $\mathrm{Mn}$ utilizando el escenario 2 (movimiento de agua y sedimentos suspendidos, ciclo 2). Los puntos de inserción (....) muestran las variaciones de las concentraciones de dos sitios del sistema hasta que se alcanza un estado estable. Experimentos, $A(-)$ y $B(--)$, unidades arbitrarias (AU).

fairly stable (tank A) or slightly increased (tank B) in the case of cobalt. The final measurements were made at evaporation factors well above those required for halite precipitation and showed a general increase in the ratio, perhaps partly due to the precipitation of inorganic salts.

In Figure $6 c$, the concentration of free (unadsorbed) radiotracers is plotted as tracer: $\mathrm{Cl} / \mathrm{oo}$ specific activity ratios. The tracer behaved in a non-conservative manner with initial remotion from solution $(\mathrm{Cl}=$
$\left\{M^{*}\right\}$ (inicial) $/\left\{M^{*}\right\}$ (final) (de ecuación 5 ), es graficada con respecto a la clorinidad. Los resultados del experimento $B$ fueron generalmente inferiores a los del experimento $\mathrm{A}$. La razón incrementa fuertemente en el intervalo de clorinidad $20-50 \%$ oo, alcanzando un máximo cerca de $45 \%$ oo (55\% /oo en el caso de $\mathrm{Mn}$, tanque B). Después de este máximo, la razón decrece constantemente en el caso del manganeso (a $50 \%$ y $30 \%$ del máximo en los tanques B y A, respectivamente) y permanece suficientemente estable (tanque A) $o$ incre- 
20-30\% $/$ oo) in both experiments. In experiment $A$, a period of roughly conservative behaviour followed $(\mathrm{Cl}=34 \%$ oo to about $120 \%$ oo) with evidence of desorption at higher chlorinities. In experiment $B$, the specific activity ratio increased from a minimum at $26 \%$, attaining stable values above $100 \%$ oo.

\section{DISCUSSION}

The various processes contributing to the observed behaviour of trace metals in the lagoon will be discussed according to the two stages described for the field data. The more general implications of these results will then be summarized.

\section{Stage I (loss of trace metals)}

The loss of trace metals to the sediments over the chlorinity range $20-50 \%$ may be accounted by the precipitation of new mineral phases, solid solution formation or adsorption to the suspended load or to sediments. The precipitation of authigenic trace metal minerals was reviewed by Murray and Brewer (1977). In most cases, the solubility concentration of the least soluble trace metal species in seawater is at least an order of magnitude higher than the natural concentrations observed in the present work. In the case of iron and manganese, the oxidation state is critical, $\mathrm{Fe}(\mathrm{III})$ and $\mathrm{Mn}(\mathrm{IV})$ being very insoluble. Colloidal $\mathrm{Fe}$ (III) appears to dominate the marine chemistry of this element whilst manganese probably exists as metastable $\mathrm{Mn}$ (II) which would be soluble under present conditions $\left(\mathrm{K}_{\mathrm{sp}}\right.$ Rhodochrosite $=2.6 \times 10^{-11}$. Johnson, 1982). From a simple physical chemical standpoint therefore, authigenic trace metal minerals should not precipitate in stage 1 , though in the case of $\mathrm{Fe}$ (III), the increased ionic strength of the medium may have accentuated colloid aggregation and precipitation.

Solid solution formation (coprecipitation) is generally considered to be a fundamental process controlling the distribution of trace metals in estuaries, where flocculating iron and manganese hydroxides appear to coprecipitate other metals (Bewers and Yeats, 1981). This effect also occurs with humic acid flocculation at about $\mathrm{Cl} \mathrm{8 \%} / 00$ (Sholkovitz, 1976). Rivers provide the large source of these carrier substances. The present case is quite menta ligeramente (tanque B) en el caso de cobalto. Las mediciones finales fueron realizadas a factores de evaporación por encima de los requeridos para la precipitación de la halita y mostraron un incremento general en la razón, quizá debido a la precipitación de sales inorgánicas.

En la Figura $6 c$, la concentración de radiotrazadores libres (absorbidos) es graficada como la razón de actividad específica trazador: $\mathrm{Cl}^{\circ} / \mathrm{oo}$. El trazador se comporta de una manera no conservativa, con remoción inicial desde la solución $(\mathrm{Cl}=20-30 \%$ oo $)$ en ambos experimentos. En el experimento $\mathrm{A}$, un período de comportamiento fuertemente conservativo $\left(\mathrm{Cl}=34^{\circ} \%\right.$ oo hasta $\left.120^{\circ} / \mathrm{oo}\right)$ con evidencias de desorción a clorinidades mayores. En el experimento B, la razón de actividad especifica incrementa desde un mínimo a $26 \%$ oo, alcanzando valores estables arriba de $100 \%$ oo.

\section{DISCUSION}

Los procesos que contribuyen al comportamiento observado de los metales traza en la laguna son discutidos de acuerdo a los dos estados descritos para los datos de campo. Las implicaciones más generales de estos resultados son resumidas.

\section{Estado I (pérdida de metales traza)}

La pérdida de metales traza hacia los sedimentos en el intervalo de clorinidad 20-50\% oo, puede ser explicada por la precipitación de fases minerales nuevas, formación de sólidos en solución y/o absorción a la carga suspendida o al sedimento. La precipitación de minerales autigénicos de metales traza fue revisada por Murray y Brewer (1977). En la mayoría de los casos, la solubilidad de las especies de metales traza menos solubles en agua de mar, son al menos un orden de magnitud mayor que las concentraciones naturales observadas en el presente trabajo. En el caso de hierro y manganeso, el estado de oxidación es crítico, $\mathrm{Fe}$ (III) y $\mathrm{Mn}$ (IV) son muy insolubles.

Fe(III)-coloidal parece dominar la química marina de este elemento mientras que el manganeso probablemente exista como Mn(II) metal estable el cual podría ser soluble bajo las condiciones presentes $\left(K_{\mathrm{sp}}\right.$ Rodocrosita $=2.6 \times 10^{-11}$, Johnson, 1982). 
Mee and Osuna-López: Trace metal chemistry of a tropical hypersaline basin

different since the source water to the lagoon is mainly coastal seawater already depleted in these substances. The amount of iron precipitated is thus of similar magnitude to the other trace metals and it is thus highly unlikely that solid solution formation with ferric hydroxide would account for the depletion of these metals.

In the present case however, precipitation of at lease $0.7 \mu \mathrm{mol}$ of calcium carbonate $\mathrm{kg}^{-1}$ (seawater) was observed (probably as aragonite, according to Millman, 1974). Laboratory studies have demonstrated the formation of solid solutions in natural waters of calcium carbonate with $\mathrm{Sr}, \mathrm{Mn}(\mathrm{II}), \mathrm{Zn}(\mathrm{II})$, Co(II) and Cd(II) (Tsusue and Holland, 1966; Kinsman and Holland, 1969; Lorens, 1981; Franklin and Morse, 1983). The distribution coefficients of most metals decrease with increasing precipitation rates (Lorens, 1981) and are much lower in seawater than river water due to site competition with $\mathrm{Mg}^{2+}$ (Franklin and Morse, 1983). In the case of $\mathrm{Mn}$, for example, the maximum (zero growth rate) distribution coefficient in seawater $\left(25^{\circ} \mathrm{C}\right)$ is about 22.5 (Lorens, 1981) and the mole fraction of this and other trace metals in deep-sea carbonates is rather low $\left(10^{-3}-10^{-1} \%\right.$, Chester and Aston, 1976). In the present evaporation experiment, no evidence was found of solid solution formation of $\mathrm{Mn}(\mathrm{II}), \mathrm{Ni}(\mathrm{II})$ or $\mathrm{Co}(\mathrm{II})$ with carbonate. The bulk of carbonate was precipitated at $\mathrm{Cl}$ $30-65 \%$ oo over which range the $\mathrm{Mg}^{2}+$ concentration would be about 1.5-3 times that of the source seawater (Fernández et al., 1982), thus accentuating even more the site competition with this ion. In the lagoonal environment, however, with the presence of sedimentary calcium carbonate, the precipitation of this mineral occurs at much lower chlorinities (see Fig. 2 and Lazar et al., 1983) and some solid solution formation may still be possible.

The adsorption of trace metals on sediments and suspended material, first studied by Krauskopf (1956), provides a buffering mechanism crucial in maintaining trace metal concentrations in seawater well below saturation levels. The similarity between field data (Fig. 3) and the results of the tank experiments in the presence of sediments (Fig. 6b) clearly demonstrates the role of suspended sediments in the hypersaline environment. The stage I loss of metals was observed in both data sets with corresponding initial increases
Desde el punto de vista fisicoquímico, los minerales autigénicos de metales traza no podrían precipitar en el estado I, no obstante en el caso de Fe(III), el incremento de fuerza iónica del medio puede incrementar la precipitación y agregación coloidal.

La formación de sólidos en solución (coprecipitación) es generalmente considerada como un proceso fundamental que controla la distribución de metales traza en estuarios, donde la floculación de hidróxidos de hierro y manganeso parecen coprecipitar otros metales (Aston, 1978; Bewers y Yeats, 1981). Este efecto también ocurre con la floculación de los ácidos húmicos a $8 \%$ de clorinidad (Sholkovitz, 1976). Los ríos constituyen una gran fuente de estas substancias transportadoras. El presente caso es quizá diferente, dado que el suministro de agua a la laguna es principalmente agua de mar costera, ya empobrecida en estas substancias. La cantidad de hierro precipitado es de magnitud similar a la de otros metales traza y por consiguiente es poco probable que la formación de sólidos en solución con hidróxido férrico ocurra para la disminución de estos metales.

Sin embargo, en este caso la precipitación de al menos $0.7 \mu \mathrm{mol}$ de carbonato de calcio por $\mathrm{kg}^{-1}$ (agua de mar) fue observada (probablemente como aragonita, de acuerdo a Millman, 1974). Estudios de laboratorio han demostrado la formación de sólidos en solución en aguas naturales, de $\mathrm{Sr}, \mathrm{Mn}(\mathrm{II}), \mathrm{Zn}$ (II), Co(II) y Cd(II) con carbonato de calcio (Tsusue y Holland, 1966; Kinsman y Holland, 1969; Lorens, 1981; Franklin y Morse, 1983). Los coeficientes de distribución de la mayoría de los metales decrecen incrementando la velocidad de precipitación (Lorens, 1981) y son menores en agua de mar que en agua de río debido a la competición de sitios con $\mathrm{Mg}+2$ (Franklin y Morse, 1983). En el caso del Mn, por ejemplo, el coeficiente de distribución máxima (tasa de crecimiento cero) en agua de mar $\left(25^{\circ} \mathrm{C}\right.$ ) es de 22.5 (Lorens, 1981) y la fracción mol de éste y otros metales traza en carbonatos de mares profundos es un poco baja $\left(10^{-3}-10^{-10} / 00\right)$ (Chester y Aston, 1976). En el presente experimento de evaporación, no se encontraron evidencias de formación de sólido en solución de $\mathrm{Mn}(\mathrm{II}), \mathrm{Ni}(\mathrm{II})$ o $\mathrm{Co}$ (II) con carbonato. La carga de carbonato precipitó entre 30-65\% $/ 00$ de clorinidad, intervalo en el cual la concentración de $\mathrm{Mg}+2$ es aproximadamente $1.5-3$ veces la del agua de 
in $D^{\prime}$ of about 2.3 and six fold for $\mathrm{Co}$ and $\mathrm{Mn}$ respectively (Fig. 6a). In terms of variation in the number of occupied sites, the increase was observed to occur over a chlorinity range of about $20 \%$ oo to $45 \%$ oo, very similar to that observed in the field data (Fig. 3).

The increased affinity of sediments for trace metals is rather surprising considering the reported general decrease in adsorption with increasing ionic strength and concentration of particulate matter (Aston and Duursma, 1974; Di Toro et al., 1986). It would thus appear that the observed increase responds to change in the ligand chemistry of the medium or in the nature of the surface sites themselves. The largest bulk chemical change occurring in stage $\mathrm{I}$ is the precipitation of $\mathrm{CaCO}_{3}$. In seawater, less than $3 \%$ of the $\mathrm{Mn}$ (II) and $\mathrm{Zn}$ (II) are complexed by the carbonate ligand though this is more important for $\mathrm{Pb}(\mathrm{II}), \mathrm{Ni}(\mathrm{II})$ and $\mathrm{Cu}(\mathrm{II})$. The precipitation of $\mathrm{CaCO}_{3}$ however, is readily nucleated by suspended particles (Stumm and Morgan, 1981) but the consequences of this effect on the surface properties of the particles themselves is unknown. Whether or not this process leads to an increase in the number of exchangeable sites is a matter which requires more detailed investigation. Certainly, a relatively small alteration in the major ion chemistry can have a profound effect on exchange properties. As an example a change in $\mathrm{pH}$ from 7.6 to 8.0 was observed to double $D^{\prime}$ for $\mathrm{Mn}$.

A further question arises as to whether the increase in the surface sediment trace metal concentration at $\mathrm{Cl}=50-60 \%$ oo, reflects an enhanced adsorption in the environment. An increase in the the trace metal content of coastal or estuarine sediments may simply be associated with a decrease in the mean particle size (Aston, 1978). In the present case, however (Fig. 4), this is coupled in some cases with a reversal of the normal metal gradient for oxidized sediments which, in turn, suggests that there is an active introduction of metals to the sediment surface at this stage of the evaporation process.

\section{Stage II}

The first series of tank experiments (Fig. 5) showed no evidence of coprecipitation of trace metals with gypsum. It may thus be assumed that the observed behaviour of these mar (Fernández et al., 1982). Sin embargo, incrementándose los sitios de competición con este ion en medio ambiente lagunar, con la presencia de carbonato de calcio sedimentario, la precipitación de este mineral ocurre a clorinidades inferiores (ver Fig. 2 y Lazar et $a l ., 1983)$ y alguna formación sólido-solución puede ser posible.

La adsorción de metales traza en material suspendido y sedimentos estudiados inicialmente por Krauskopf (1956), constituye un mecanismo amortiguador crucial manteniendo la concentración de metales traza en agua de mar por debajo de niveles de saturación. La similitud entre los datos de campo (Fig. 3) y los resultados de los experimentos en tanques de. evaporación en presencia de sedimento (Fig. 6b) demuestra claramente el papel de los sedimentos suspendidos en el medio ambiente hipersalino. La pérdida de metales en el estado I, se observó en ambas series de datos con el correspondiente incremento inicial en $D^{\prime}$ de 2.3 y seis campos para $\mathrm{Co}$ y $\mathrm{Mn}$ respectivamente (Fig. 6). En términos de variación en el número de sitios ocupados, el incremento observado ocurrió en un intervalo de clorinidad de 20 a $45 \%$ oo, muy similar al observado en los datos de campo (Fig. 3).

$\mathrm{El}$ incremento en afinidad de sedimentos por metales traza es sorprendente considerando el decremento en adsorción publicado en general, al incrementar la concentración de materia partículada y la fuerza iónica (Aston y Duursma, 1974; Di Toro et al., 1986). De esta manera, parece ser que el incremento observado responde a un cambio en la química ligando del medio o en la naturaleza misma de los sitios superficiales (de las partículas). El gran cambio químico que sucede en el estado I es la precipitación de $\mathrm{CaCo}_{3}$. En agua de mar, menos del 3\% del $\mathrm{Mn}$ (II) y $\mathrm{Zn}$ (II) forman complejos con el ligando carbonato, no obstante ésta es más importante para $\mathrm{Pb}$ (II), $\mathrm{Ni}$ (II) y $\mathrm{Cu}$ (II) (Whitfield et al., 1981). Sin embargo la precipitación de $\mathrm{CaCO}_{3}$ es fácilmente nucleada por partículas suspendidas (Stumm y Morgan, 1981) pero las consecuencias de este efecto sobre las propiedades de superficie de las partículas en si mismas, es desconocida. De todas formas este proceso conduce a un incremento en el número de sitios intercambiables; ésta es una materia que requiere investigaciones más detalladas. Ciertamente, una alteración relativamente pequeña en la química de iones más abundantes 
Mee and Osuna-López: Trace metal chemistry of a tropical hypersaline basin

metals is largely a result of partition between the adsorbed and dissolved phases.

Cursory analysis of Figure 6a reveals that $D^{\prime}$ decreases by $90-98 \%$ with increasing chlorinity (above $35 \%$ oo) for $\mathrm{Co}$ and $\mathrm{Mn}$. Recent experiments conducted with the same solid matrix (A. Hansen, unpublished), demonstrated that the active sites were not saturated with $\mathrm{Co}_{0}$ or $\mathrm{Mn}$ under the present experimental conditions and add credance to the $D^{\prime}$ values obtained. The mole fraction of adsorbed sites (Fig. 6b) decreased in the case of $\mathrm{Mn}$ and remained fairly constant $(10 \%$ decrease, experiment $\mathrm{A}$ ) in the case of $\mathrm{Co}$, indicating a strong tendency for desorption in the former case and a weak or null tendency in the latter case. The adsorption of trace metals onto marine sediments is only partly reversible (Li et al., 1984). In the case of experiment A, the results reflected adsortion-desorption reactions as the sediment/water system passes through increasing salinities and radionuclide concentrations whereas experiment $B$ reflects only the adsorption reaction at each increasing salinity. This effect, combined with the tendency for $D^{\prime}$ to decrease at higher particle concentrations (Aston and Duursma, 1973; $\mathrm{Li}$ et al., 1984), probably explains the differences observed between experiments $\mathrm{A}$ and $\mathrm{B}$.

Three principal factors may influence the tendency for net desorption in stage II, ionic strength, the major ion concentration and $\mathrm{pH}$. The effect of ionic strength was studied for the montmorillonite- $\mathrm{NaNO}_{3}$ system by Di Toro et al. (1986). These authors estimated a decrease of about 1.4 fold in the reversible component of the partition coefficient for each order of magnitude increase in ionic strength. In the present experiment, a much larger (1-2 orders of magnitude) decrease was observed for a five fold increase in ionic strength. This may have been due, in part, to increase site competition with $\mathrm{Ca}^{2}+$ and $\mathrm{Mg}^{2}+$ with increasing seawater concentration (Hansen, 1989). The relationship between the experimentally observed desorption of $\mathrm{Mn}$ and the field data will be explored in the following section.

At later stages in the evaporation process however, rhodochrosite formation may occur. The first survey maximum of $224 \mu \mathrm{g} \mathrm{kg}^{-1}$ of dissolved manganese with an excess of carbonate would yield a molar ion product of $1.6 \times 10^{-11}$, critically close to the puede tener un efecto profundo sobre propiedades de intercambio, por ejemplo, un cambio en pH de 7.6 a 8.0 se observó que duplicó $D^{\prime}$ para $\mathrm{Mn}$.

La siguiente cuestión se planteó como el incremento en la concentración de metal traza en la superficie del sedimento a 50-60\% refleja un incremento de adsorción en el medio ambiente. Un incremento en el contenido de metal traza de sedimentos costeros o estuarinos, puede ser simplemente asociado con un decremento en el tamaño medio de partículas (Aston, 1978). En el presente caso, sin embargo (Fig. 4), está acoplado en algunos casos con una inversión del gradiente metálico normal para sedimentos oxidados, lo cual, a su vez, sugiere que existe una introducción activa de metales a la superficie del sedimento en esta etapa del proceso de evaporación.

\section{Estado II}

La primera serie de experimentos en laboratorio (Fig. 5) no mostró evidencia de coprecipitación de metales traza con gibbsita; puede asumirse que el comportamiento observado de estos metales es en gran parte resultado de la participación entre fases disueltas y adsorbidas.

El análisis superficial de la Figura 6a revela que $D^{\prime}$ para Co y $\mathrm{Mn}$ decrece en 90-98\% cuando la clorinidad incrementa (arriba de $35 \%$ oo). Experimentos recientes, realizados con la misma matriz sólida (A. Hansen, no publicados), demuestran que los sitios activos no fueron saturados con Co o Mn bajo las condiciones experimentales y añade credibilidad a los valores obtenidos de $D^{\prime}$. La fracción mol de sitios adsorbidos (Fig. 6b) decrece en el caso de $\mathrm{Mn}$ y permanece relativamente constante (decrece $10 \%$, experimento A), en el caso de $\mathrm{Co}$, indicando una tendencia fuerte por desorción en el primer caso y una tendencia débil o nula en el último. La adsorción de metales traza en sedimentos marinos es sólo parcialmente reversible ( $\mathrm{Li}$ et al., 1984). En el caso del experimento A, los resultados reflejan reacciones de adsorcióndesorción como ruta entre agua/sedimento al incrementarse las salinidades y concentración de radionúclidos, mientras el experimento $B$ refleja solamente reacciones de adsorción a cada incremento de salinidad. Este efecto, combinado con la tendencia por decrecer de 
literature values in the range of $1.8 \times 10^{-11}$ to $3.9 \times 10^{-11}$ for $\mathrm{K}_{\mathrm{sp}}$ rhodochrosite (Franklin and Morse, 1983). Rhodochrosite precipitation at high salinity may also explain the apparently simultaneous precipitation of $\mathrm{Mn}$ and $\mathrm{NaCl}$ in the first series of tank experiments.

\section{Overall comparison of laboratory and field observations}

The present laboratory experiments demonstrate the variations in water/sediment partition of trace metals in an isolated, homogeneous basin. The ficld data, however, relates to an open system in which a dynamic horizontal salinity gradient is established across lagoon sediments, from seawater at one extreme, to halite at the other. In order to relate the batch experiments to an open system in a descriptive manner, a simple model was devised. The model lagoon consisted of a long shallow evaporating channel of unit depth, open to the sea at one end and in which halite is precipitating at the other. The system is characterized by descrete homogeneous parcels of water flowing inwards and, as they evaporate, increasing in chlorinity (from 20.90\% oo to dry salt) and losing volume. made:

Various simplifying assumptions are

(1) There is no mixing between parcels (tidal mixing, reverse flow, etc.).

(2) The rate of horizontal transport is sufficiently slow (and the parcels sufficiently large) to permit equilibrium with the sediments.

(3) A steady-state distribution of chlorinity is rapidly achieved.

(4) Each kilogram of water is in equilibrium with $20 \mathrm{~g}$ of sediment, $10 \%$ of which is in suspension at any one moment (figures arbitrarily selected for the purpose of the model).

The trace metal partition in such a parcel of water as it moves through the system may be predicted using the experimental values of $D^{\prime}$ and equation (1). The total metal in each parcel, on passing from one mean chlorinity to another, consists of that which was previously adsorbed in the sediments (initially this will be the equilibrium concentration with coastal scawater throughout the lagoon) together with the dissolved metal transferred from the preceding equi-
$D^{\prime}$ a concentraciones elevadas de partículas (Aston y Duursma, 1973; Li et al., 1984), probablemente explica las diferencias observadas entre ambos experimentos.

Tres factores principales pueden influir la tendencia neta por desorción en el estado II: fuerza iónica, la concentración de iones más abundantes y el $\mathrm{pH}$. El efecto de la fuerza iónica fue estudiada para el sistema $\mathrm{NaNO}_{3}$-Montmorillonita por $\mathrm{Di}$ Toro et al. (1986). Estos autores estimaron un decremento de 1.4 veces en el componente reversible del coeficiente de partición para cada incremento en orden de magnitud de la fuerza iónica. En el experimento presente, un decremento mucho mayor (1-2 órdenes de magnitud) se observó para un incremento de cinco veces en fuerza iónica. Esto puede deberse, en parte, al incrementar los sitios de competencia con $\mathrm{Ca}+2$ y $\mathrm{Mg}+2$ con el incremento en concentración de agua de mar (Hansen, 1989). La relación entre la desorción de Mn observada experimentalmentey los datos de campo serán explicados en la siguiente sección.

La formación de rodocrosita puede ocurrir en el último estado del proceso de evaporación. El máximo de $224 \mu \mathrm{g} \cdot \mathrm{kg}^{-1}$ de manganeso disuelto, analizado durante el primer muestreo, con un exceso de carbonato produciría un producto iónico molar de 1.6 x 10-1, críticamente cercano a los valores publicados para $K_{\mathrm{sp}}$ de rodocrosita, en el intervalo de $1.8 \times 10^{-1}$ a $3.9 \times 10^{-11}$ (Franklin y Morse, 1983). La precipitación de rodocrosita a salinidades altas puede también explicar la precipitación aparentemente simultánea de $\mathrm{Mn}$ y $\mathrm{NaCl}$ en la primera serie de experimentos en tanques.

\section{Comparación global de observaciones de campo y laboratorio}

Los experimentos de laboratorio demuestran la variación en partición agua/sedimento de metales traza en una cuenca homogénea, aislada. Sin embargo, los datos de campo se refieren a un sistema abierto en el cual un gradiente de salinidad dinámico-horizontal se establece a través de los sedimentos lagunares, desde agua de mar en un extremo hasta halita por el otro. Un modelo simple fue ideado, con el objeto de relacionar la serie de experimentos de una manera descriptiva, a un sistema abierto. El modelo lagunar consiste de un canal de evaporación somero, largo y de 
librium condition and concentrated by evaporation.

Two versions of this model were developed, one in which only water was transported through the system (model 1) and another in which suspended sediments were also transported (model 2). The models were cycled until a steady-state was achieved. In Figure 7, the results for the second cycle are illustrated and (as insets), the variations with time in metal concentrations at two points in the system until steady-state is recorded. The time equivalent of each cycle is a function of lagoon morphology, evaporation and adsorption kinetics. For the Ceuta lagoon, it would take about 80 days for a parcel of water to evaporate to dryness and it is unlikely that a steady-state is ever achieved.

Despite the evident simplifications of the model (e.g, in the real system, full equilibrium between the mobile and stationary phases may not be achicved), it satisfactorily reproduces the major features of the field data, notably the initial loss of $\mathrm{Mn}$ to the sediments and a secondary increase in dissolved $\mathrm{Mn}$ at higher chlorinites due to desorption. The desorption loss is initially large and depends on the adsorbed trace metal concentration in the sediments before the onset of hypersalinity. The peak of dissolved metal concentration at this point (point II in Fig. 8) gradually decreases to a minimum at about nine cycles (model 2) or 200 cycles (model 1) as the exchangeable $\mathrm{Mn}$ in the sediments is exhausted. Following the saturation of active sites seawards from point II, the concentration gradually increases again to reach a steady state at about 55 cycles (model 2) or 480 cycles (model 1 ). The steady-state concentration is lowest where sediments are transported. In the case of no sediment transportation, the final steady state corresponds to a system in which dissolved trace metals are conservative owing to the saturation of all active adsorption sites.

The model provides a possible explanation for the field observations of a stage II maximum. The first data set probably corresponds to the first few cycles of the model (as the lagoon is hypersaline during only part of the year). The observed maximum is probably the result of strong desorption of metals adsorbed on the surface sediments during the period when the lagoon acts as an estuary. As the hypersaline period progresses (second data profundidad unitaria, abierto al océano por un lado y halita precipitando por el otro.

El sistema se caracteriza por parcelas de agua homogéneas fluyendo hacia el interior, perdiendo volumen $\mathrm{e}$ incrementando en clorinidad por evaporación, desde 20.9\% hasta evaporación total.

Se hacen las siguiente consideraciones:

1. No existe mezclado entre parcelas (mezclado por mareas, reflujo, etc.).

2. La velocidad de transporte horizontal es suficientemente lenta ( $y$ las parcelas suficientemente grandes) para alcanzar el equilibrio con los sedimentos.

3. Una distribución de clorinidad en estado estable se alcanza rápidamente.

4. Cada kilogramo de agua está en equilibrio con $20 \mathrm{~g}$ de sedimento, $10 \%$ del cual está en suspensión en todo momento (figuras seleccionadas arbitrariamente para fines del modelo).

La partición metal traza de esta índole en la parcela de agua desplazándose a través del sistema puede predecirse utilizando los valores experimentales de $D^{\prime}$ y la ccuación (1). El metal total en cada parcela, pasando de una clorindiad media a otra, consiste del adsorbido previamente en los sedimentos (inicialmente ésta será la concentración de equilibrio con agua de mar costera a través de la laguna) junto con el metal disuelto transferido desde la condición de equilibrio precedente y concentrada por evaporación.

Se desarrollaron dos versiones del modelo, una en la cual solamente agua fue transportada a través del sistema (modelo 1) y otra en la cual, sedimentos suspendidos fueron también transportados (modelo 2). Los modelos fueron reciclados hasta alcanzar un estado estable. En la Figura 7, se ilustran los resultados para el segundo ciclo y (como recuadro) las variaciones de concentración del metal con el tiempo se registraron en dos puntos del sistema hasta alcanzar el estado estable. El tiempo equivalente de cada ciclo está en función de la cinética de adsorción, evaporación y morfología de la laguna. Para la laguna Ceuta, la evaporación a sequedad de una parcela de agua, podría llevar cerca de 80 días y es poco probable que un estado estable sea alcanzado siempre.

A pesar de las simplificaciones evidentes del modelo (e.g. en el sistema real, el equilibrio completo entre fases móviles y estacionarias, no puede ser alcanzada), éste reproduce satis- 
set), the desorption and water column metal concentrations decreases (as predicted by the model). In both the field data and model predictions, the sedimentary $\mathrm{Mn}$ concentrations exhibit a small maximum at low chlorinities (the field data peak is probably broadened by tidal mixing) and the concentration then decreases at higher chlorinities due to desorption and dilution by evaporites.

How do these results compare with other systems? Unfortunately, there is little field data to permit comparisons. According to Borchert (1965) and Holser (1979a,b), most historical evaporite deposits were formed in a series of connecting epicontinental basins, similar to the present system though on a much larger scale. Borchert (1965), observed evidence of seasonal variations in halite deposition in the Zechstein deposits and Holser (1979a) mentions the importance of clay minerals often associated with evaporites (evidence of active sediment transport in the system). It seems reasonable to suppose that many of these ancient systems achieved a geochemical steady-state with respect to trace metals and, depending upon the extent of sediment transport, these components may have been virtually conservatively concentrated in the water column. Many of the ancient systems were sufficiently deep to permit subsurface seaward flow-back of part of the concentrated brines (Borchert, 1965) which must have considerably modified their trace metal chemistry.

\section{CONCLUSIONS}

The distribution of trace metals in hypersaline lagoons is a consequence of the concentration of seawater by evaporation and the variation, with increasing chlorinity, of the partition of the metals between the dissolved and adsorbed (sedimentary) phases. Coprecipitation of the metals with calcium carbonate, metal hydroxides or gypsum, does not appear to play a significant role in their distribution. Three processes dominate the distribution of trace metals in the Ceuta lagoon: stage $I$, chlorinity $20-50 \%$ oo, enhanced adsorption (loss of metals to the sediments); stage II, chlorinity 50-157\% $/ 00$, net desorption (loss of metals from the sediments) and stage III, precipitation of halite and the last bitters (precipitation or coprecipitation of metals). factoriamente dos rasgos principales de los datos de campo, notablemente la pérdida inicial de manganeso hacia los sedimentosy un incremento secundario en manganeso disuelto a clorinidades elevadas debido a la desorción. La eliminación por desorción es inicialmente grande y depende de la concentración del metal traza adsorbido en los sedimentos antes del inicio de hipersalinidad. El pico de concentración de metal disuelto en este punto (Fig 8 , punto II) decrece gradualmente a un mínimo cercano a nueve ciclos (modelo 2) o 200 ciclos (modelo 1) a medida que el $\mathrm{Mn}$ intercambiable en los sedimentos es agotado. Continuando la saturación de sitios activos hacia el mar desde el punto II, de nuevo la concentración incrementa gradualmente alcanzando un estado estable cerca de los 55 ciclos (modelo 2) o 480 ciclos (modelo 1). La concentración en estado estable es inferior cuando los sedimentos son transportados. En el caso de ningún transporte de sedimento, el estado estable final corresponde a un sistema en el cual los metales traza disueltos son conservativos debido a la saturación de todos los sitios de adsorción activos.

El modelo proporciona una posible explicación para las observaciones de campo en un estado II máximo. La primera serie de datos corresponden probablemetne a los primeros pocos ciclos del modelo (ya que, la laguna permanece hipersalina sólo durante una época del año). El máximo observado es probablemente resultado de desorción fucrte de metales adsorbidos sobre los sedimentos superficiales durante el periodo en el cual la laguna actúa como un estuario. A medida que avanza el periodo hipersalino (segunda serie de datos), la desorción y concentraciones de metales en la columna de agua decrece (como predice el modelo). Tanto en los datos de campo como en predicciones del modelo, las concentraciones sedimentarias de Mn exhiben un pequeño máximo a bajas clorinidades (el pico de datos de campo es probablemente más amplio por mezclado de mareas), y la concentración por consiguiente decrece a clorinidades elevadas debido a desorción y dilución por evaporitas

¿Cómo son estos resultados comparados con otros sistemas? Desafortunadamente existen pocos datos de campo que permitan comparaciones. De acuerdo a Borchert (1965) y Holser (1979a,b), la mayoría de los depósitos de evaporitas históricos fueron formados en 
Mee and Osuna-López: Trace metal chemistry of a tropical hypersaline basin

\section{ACKNOWLEDGEMENTS}

The authors are grateful to Alberto Castro del Rio and staff of the Mazatlán field station of the Instituto de Ciencias del Mar y Limnología of the Universidad Nacional Autónoma de México for their help during the field studies and $\mathbf{M}$. Rosenbaum, director, and the staff of the Centro de Ciencias Nucleares of the same university for their support during part of the laboratory studies. The senior author wishes to thank R. Fukai, former director, and A. Walton, present director, of the International Laboratory for Marine Radioactivity (ILMR-IAEA), Monaco, for making laboratory facilities available during his sabbatical leave. The late $S$. Aston gave valuable advice, $N$. Whitchead is thanked for practical support and D. Quaniche for technical assistance at ILMR. Thanks to Margarita Cordero R., Mariana Hernández G. and Sonia Osuna $\mathbf{P}$. for their assistance in the preparation of this manuscript.

\section{LITERATURE CITED}

Abdullah, M.I., El-Rayis, O.A. and Riley, J.P. (1976). Re-assessment of chelating ion-exchange resins for trace-metal analysis of sea water. Analytical Chim. Acta, 84: 363-368.

Aston, S.R. (1978). Estuarine chemistry. In: J.P. Riley and R. Chester (eds.), Chemical Oceanography, 2nd Edn. Academic Press, London, 7: 361-441.

Aston, S.R. and Duursma, E.K. (1974). Concentration effects on ${ }^{136} \mathrm{Cs}, 65 \mathrm{Zn}, 60 \mathrm{Co}$ and $106 \mathrm{Ru}$ sorption by marine sediments, with geochemical implications. Neth. J. Sea Res., 6: 225-240.

Bertine, K.K. and Schug, D. (1981). Man and the historical sedimentary record in two semi-arid estuaries. In: UN, UNEP, IOC, SCOR (eds.), River Inputs to Ocean Systems. United Nations Publ., New York, pp. 329-342.

Bewers, J.M. and Yeats, P.A. (1981). Behaviour of trace metals during estuarine mixing. In: UN, UNEP, IOC, SCOR (eds.), River Inputs to Ocean Systems. United Nations Publ., New York, pp. 103-115. una serie de cuencas epicontinentales conectadas, similares a los sistemas presentes pero en escala mayor. Borchert (1965) observó evidencias de variaciones estacionales en la depositación de halita en los depósitos Zechstein y Holser (1979a) menciona la importancia de minerales arcillosos asociados frecuentemente con evaporitas (evidencia del transporte activo de sedimento en el sistema). Parece razonable suponer que muchos de estos sistemas antiguos alcanzaron un estado geoquímico estable con respecto a metales traza y, dependiendo de la extensión del transporte de sedimentos, estos componentes pudieron haber sido concentrados virtual y conservativamente en la columna de agua.

Muchos de los sistemas anciestos fueron suficientemente profundos para permitir reflujo hacia la subsuperficie del mar desde las salmueras concentradas en el fondo (Borchert, 1965), to cual pudo haber modificado considerablemente su química de metales traza.

\section{CONCLUSIONES}

La distribución de metales traza en lagunas hipersalinas es consecuencia de la concentración de agua de mar por evaporación y la variación del incremento de clorinidad, de la partición de los metales entre las fases adsorbidas (sedimentarias) y disueltas. La coprecipitación de los metales con carbonato de calcio, hidróxidos metálicos y/o gibbsita, no parece desempeñar un papel significante en su distribución. Tres procesos dominan la distribución de metales traza en la laguna Ceuta: estado I, clorinidad $20-50 \%$ oo, adsorción incrementada (pérdida de metales hacia los sedimentos); estado II, clorinidad 50-157\% /oo, desorción neta (pérdida de metales desde los sedimentos) y estado III precipitación de halita y las últimas sales de la salmuera (precipitación o coprecipitación de metales).

\section{AGRADECIMIENTOS}

Los autores agradecen a Alberto Castro del Río y personal de la Estación Mazatlán del Instituto de Ciencias del Mar y Limnología de la Universidad Nacional Autónoma de México por su ayuda durante los estudios de campo. Al personal y director, M. Rosenbaum, del Centro de Ciencias Nucleares de la misma universidad, por su apoyo durante parte de los 
Bcwers, J.M., Yeasts, P.A., Westerlund, S., Magnusson, B., Schmidt, D., Zehle, H., Berman, S.S., Mykytiuk, A., Duinker, J.C., Nolting, R.F., Smith, R.G. and Windom, H.L. (1985). An intercomparison of seawater filtration procedures. Mar Pollut. Bull., 16: 277-281.

Borchert, H. (1965). Principles of oceanic salt deposition and metamorphism. In: J.P. Riley and G. Skirrow (eds.), Chemical Oceanography, Vol. 2. Academic Press, London, pp. 205-276.

Brian, G.W. (1976). Heavy metal contamination in the sea. In: R. Johnson (ed.), Marine Pollution. Academic Press, London, pp. 185-302.

Chester, R. and Aston, S.R. (1976). The geochemistry of deep-sea sediments. In: J.P. Riley and R. Chester (eds.), Chemical Oceanography, 2nd Edn. Academic Press, London, Vol, 6: 281-390.

Copeland, B.J. (1967). Environmental characteristics of hypersaline lagoons. Univ. Tex. Contrib. Mar. Sci., 12: 207-218.

Davis, J.A. and Leckic, J.O. (1978). Surface ionization and complexation at the oxide/water interface VI. Surface properties of amorphous iron oxyhydroxide and adsorption of metal ions. J. Colloid Interface Sci., 67: 90-107

De Luca Rebello, A., Hackel, W., Moreira, I., Santelly, R. and Schroeder, F. (1986). The fate of heavy metals in an estuarine tropical system. Mar. Chem., 18: 215-225.

Di Toro, D.M., Mahony, J.O., Kirchgraber, P.R., O'Byrne, A.L., Pasquale, L.R. and Picirilli, D.C. (1986). Effects of nonreversibility, particle concentration, and ionic strength on heavy metal sorption. Environ. Sci. Technol., 20: 55-61.

Duursma, E.K. and Bosch, C.J. (1970). Theoretical, experimental and field studies concerning diffusion of radioisotopes in sediments and suspended particles of the sea. Part B: Methods and experiments. Neth. J. Sea Res., 4: 395-469.

Duursma, E.K. and Hoede, C. (1967). Theoretical experimental and field studies concerning diffusion of radioisotopes in sediments and suspended particles of the sea. Part B: methods and experiments. Neth. J. Sea Res., 4: 395-469. estudios de laboratorio. El primer autor agradece a R. Fukai y A. Walton, ex-director y director respectivamente, del Laboratorio Internacional de Radioactividad Marina (ILMR-LAEA), Mónaco, por las facilidades brindadas durante su estancia sabática. El difunto S. Aston brindó invaluable asesoria; a N. Whitehead se agradece su apoyo práctico y a D. Quaniche por su asistencia técnica en el ILMR A María Margarita Cordero R., Mariana Hernández G. y Sonia Osuna P., por su asistencia en la elaboración del manuscrito.

Traducido al español por los autores.

Edmond, J.M: (1970). High precision determination of titration alkalinity and total carbon dioxide content of sea water by potentiometric titration. Deep-Sea Res., 17: $737-750$.

Fernández, H. y Mce, L.D. (1980). Variación de la concentración de algunos iones en el agua de la laguna de Apozahualco, Guerrero, México. An. Centro Cienc. del Mar y Limnol., UNAM, México, 7: 33-37.

Fernández, H., Vázquez, F. and Millero, F. (1982). The density and composition of hypersaline waters of a Mexican lagoon. Limnol. Oceanogr., 27: 315-321.

Franklin, M.K. and Morse, J.W. (1983). The interaction of manganese (II) with the surface of calcite in dilute solutions and seawater. Mar. Chem., 12: 241-254.

Fukai, R. and Huynh-Ngoc, L. (1968). Studies on the chemical behaviour of radionuclides in sea water. I. General considerations, and study of precipitation of trace amounts of chromium, manganese, iron, cobalt, zinc and cerium. Radioactivity in the sea No. 22, I.A.E.A., Vienna, $26 \mathrm{pp}$.

Gran, G., (1952). Determination of the equivalence point in potentiometric titrations. Part II. Analyst, 77: 661-671.

Hansen, A.M. (1989). Adsorción de cobalto en sedimentos marinos: Evaluación experimental y simulación numérica. Tesis de Doctorado, UNAM, 132 pp.

Herrmann, A.G., Knake, D., Schneider, J. and Peters, H. (1973). Geochemistry of modern seawater and brines from salt 
pans: Main components and bromine distribution. Contrib. Mineral Petrol., 40: $1-24$.

Holser, W.T. (1979a). Mineralogy of evaporites. In: R.G. Burns (ed.), Marine Minerals. Mineralogical Soc. of America, Washington, pp. 211-294.

Holser, W.T. (1979b). Trace elements and isotopes in evaporites. In: R.G. Burns (ed.), Marine Minerals. Mineralogical Soc. of America, Washington, pp. 295-346.

Hsu, K.J. (1972). Origin of the saline giants: A critical review after the discovery of the Mediterranean cvaporite. Earth Sci Rev., 8: 371-396.

Hsu, K.J., Montadert, L., Bernoulli, D., Cita, M.B., Erikson, A., Garrison, R.E., Kidd, R.B., Melieres, X., Muller, C. and Wright, R. (1977). History of the Mediterranean salinity crisis. Nature, 267: 399-403.

I.A.E.A. (1985). Sediment $K_{d}$ s and concentration factors for radionuclides in the marine environment. Tech. Reports Series 247, International Atomic Energy Agency, Vienna, $73 \mathrm{pp}$.

Johnson, K.S. (1982). Solubility of rhodochrosite $\left(\mathrm{MnCO}_{3}\right)$ in water and seawater. Geochim. Cosmochim. Acta, 46: 1805-1809.

Kinsman, D.J.J. and Holland, H.D. (1969). The co-precipitation of cations with $\mathrm{CaCO}_{3}$. IV. The co-precipitation of $\mathrm{Sr}^{2}+$ with aragonite between 16 and 960C. Geochim. Cosmochim. Acta, 33: $1-17$.

Krauskopf, K.B. (1956). Factors controlling the concentrations of thirteen metals in sea water. Geochim. Cosmochim. Acta, 9: $1-32$.

Krumgaltz, B.S., Hornung, H. and Oren, O.H. (1980). The study of natural hypersaline lagoons in desert areas (the Bardawil lagoon in northern Sinai). Estuar. Coast. Mar. Sci., 10: 403-415.

Lankford, R.R. (1977). Coastal lagoon of Mexico - their origin and classification. In: M. Wiley (ed.), Estuarine Processes, Vol. 2. Academic Press, New York, pp. 182-215.

Lazar, B., Starinsky, A., Katz, A., Sass, E. and Ben-Yaakov, S. (1983). The car- bonate system in hypersaline solutions: Alkalinity and $\mathrm{CaCO}_{3}$ solubility of evaporated seawater. Limnol. Oceanogr., 28: 978-986.

Li, Y-H, Buchholtz, M., O'Hara, P. and Santschi, P.H. (1984). Partition of radiotracers between suspended particles and seawater. Geochim. Cosmochim. Acta, 48: 2011-2014.

Lorens, R.B. (1981). Sr, Cd, $\mathrm{Mn}$ and $\mathrm{Co}$ distribution coefficients in calcite as a function of calcite precipitation rate. Geochim. Cosmochim. Acta, 45: 553-561.

Mee, L.D. (1978). Coastal lagoons. In: J.P. Riley and R. Chester (eds.), Chemical Oceanography, 2nd. Edn. Academic Press, London, 7: 441-490.

Millero, F.J. (1974). Seawater as a multicomponent electrolyte solution In: E.D. Goldberg (ed.), The Sea. Wiley, New York, 5: 3-80.

Millman, J.D. (1974). Marine Carbonates. Springer-Verlag, Berlin, 375 pp.

Moore, N.H. and Slinn, D.J. (1984). The physical hydrology of a lagoon system on the Pacific coast of Mexico. Estuar. Coast. Shelf Sci., 19: 413-427.

Murray, J.W. and Brewer, P.G. (1977). Mechanisms of removal of manganese, iron and other trace metals from sea water. In: G.P. Glasby (ed.), Marine Manganese Deposit. Elscvier Oceanography Series, 15: 291-325.

Nyffler, U.P., Li, Y-H. and Santschi, P.H. (1984). A kinetic approach to describe trace-element distribution between particles and solution in natural aquatic systems. Geochim. Cosmochim. Acta, 48: $1513-1522$.

Riley, J.P. and Taylor, D. (1968). Chelating resins for the concentration of trace elements from seawater and their analytical use in conjuntion with atomic absorption spectrophotometry. Analytica Chim. Acta, 40: 479-485.

Sholkovitz, E.R. (1976). Flocculation of dissolved organic and inorganic matter during the mixing of river water and seawater. Geochim. Cosmochim. Acta, 40: 831-845.

Strickland, J.D.H. and Parsons, T.R. (1972). A practical handbook of seawater analy- 
sis. Bull. No. 167, Fisheries Res. Bd. Canada.

Stumm, W. and Morgan, J. (1981). Aquatic Chemistry, 2nd. Edn. Wiley, New York, $583 \mathrm{pp}$

Tsusue, A. and Holland H.D. (1966). The coprecipitation of cations with $\mathrm{CaCO}_{3}$ III. The coprecipitation of $\mathrm{Zn}^{2}+$ with calcite between 50 and $250^{\circ} \mathrm{C}$. Geochim. Cosmochim. Acta, 30: 439-453.
Usiglio, G. (1849). Analyse de l'eau de la Mediterranee sur les cotes de France. Annalen der Chemie, 27: 92-107. 172-191.

Whitfield, M., Turner, D.R. and Dickson, A. (1981). Speciation of dissolved constituents in estuaries. In: UN, UNEP, IOC, SCOR (eds.), River Inputs to Ocean Systems. United Nations Publ., New York, pp. 132-149. 